\title{
Article \\ A Bid/Mark-Up Decision Support Model in Contractor's Tender Strategy Development Phase Based on Project Complexity Measurement in the Downstream Sector of Petroleum Industry
}

\author{
Amir Faraji ${ }^{1,2, *(\mathbb{D}}$, Maria Rashidi ${ }^{2}$, Navid Ahmadi Eftekhari ${ }^{3}\left(\mathbb{C}\right.$, Srinath Perera $^{2}\left(\mathbb{D}\right.$ and Saba Mani ${ }^{3}(\mathbb{C}$ \\ 1 Construction Project Management Department, Faculty of Architecture, Khatam University, \\ Tehran 1991633357, Iran \\ 2 School of Engineering, Design and Built Environment, Western Sydney University, \\ Penrith, NSW 2751, Australia; m.rashidi@westernsydney.edu.au (M.R.); \\ Srinath.perera@westernsydney.edu.au (S.P.) \\ 3 Faculty of Architecture and Urban Planning, University of Art, Tehran 1136813518, Iran; \\ navid.eftekhari@hotmail.com (N.A.E.); saba.mani@hotmail.com (S.M.) \\ * Correspondence: a.faraji@khatam.ac.ir or a.faraji@westernsydney.edu.au
}

Citation: Faraji, A.; Rashidi, M.; Eftekhari, N.A.; Perera, S.; Mani, S. A Bid/Mark-Up Decision Support Model in Contractor's Tender Strategy Development Phase Based on Project Complexity Measurement in the Downstream Sector of Petroleum Industry. J. Open Innov. Technol. Mark. Complex. 2022, 8, 33. https://doi.org/10.3390/ joitmc 8010033

Received: 17 October 2021 Accepted: 10 December 2021 Published: 3 February 2022

Publisher's Note: MDPI stays neutral with regard to jurisdictional claims in published maps and institutional affiliations.

Copyright: (C) 2022 by the authors Licensee MDPI, Basel, Switzerland. This article is an open access article distributed under the terms and conditions of the Creative Commons Attribution (CC BY) license (https:// creativecommons.org/licenses/by/ $4.0 /)$.

\begin{abstract}
The tender process is an inseparable step of the contract award process in the public sector, and from the other point of view, it is one of the crucial elements of the core business of construction contractors. Reviewing previous research reveals a gap in the application of a project's detailed features and historical data to support the bid/no-bid decision and to determine the cost and time contract mark-ups. In this study, a prescriptive project complexity-based model is proposed to support the bid decision in the tender strategy development phase of a contractor for the downstream sector of the petroleum industry in Iran. For this purpose, regression analysis of historical data is adopted to configure the model and to infer from previous actual trends by exploring relationships between the contractor's bid decision and proposed mark-ups with the project's inherent and surrounding complexity factors. Hence, using experts' opinions and historical data from 139 previous contracts as training and test data, a model was developed to make a decision on a bid and mark-up problem. The results of the model validation show that the credibility of the model is $74.67 \%$ and $75.36 \%$ for time and cost, respectively, and the reliability of model outputs is approximately $90 \%$ overall in predicting the bid mark-ups in accordance with the project complexity index (PCI). The main contribution of this research to current knowledge has two aspects: utilizing the complexity concept for the tender problem in the form of a project complexity index (PCI) and considering both time and cost mark-ups (TMU-CMU) in the contractor's bid simultaneously. In addition, the results show that the more complex the project is, the higher the bid rate is.
\end{abstract}

Keywords: bid mark-ups; tender strategy; project complexity; construction management; public sector; open innovation dynamics

\section{Introduction}

To develop their business and to maximize their revenue, construction contractors can follow the two options of direct negotiation with potential clients or participation in competitive bids [1]. Based on government reports, on average, more than 400 to 500 tender advertisements are published daily in Iran and mainly by public bodies; therefore, having knowledge about preparing appropriate bid proposals is vital for contractors. The tender method is one of the most common ways of buying implementation services in the construction industry, especially where the client side of the project is the government or the public sector [2,3]. Additionally, the tender technique is well known as the second critical stage in a traditional approach of a project delivery system called design-bid-build (DBB), which is the predominant method of construction delivery in the public sector in Iran. Although a tender can be fulfilled in different ways, such as public or limited, with 
one stage or two stages and by considering many factors, the main principles of a tender have remained unchanged. The bid or no-bid and the tender mark-up percentage are key decisions that must be made repeatedly by qualified contractors involved in projects in the Iranian downstream sector [4]. The above-mentioned decision includes two major parts: preparation and presentation of a proposal and refusal to participate in the tender; and in the case of a decision to submit a bid, the determination of the relevant time and cost should be proposed. Generally, the term mark-up refers to an allowance for profit plus general overhead [5]. Therefore, the proposal mark-up will act as the coverage for contractors' risk in terms of time and cost factors. However, in the context of this research, a tender strategy from the contractor's point of view [6-8], the effective factors of a bid/no-bid decision $[9,10]$ and the model development for improving bid/no-bid and mark-up percentage decision making $[9,11,12]$ are investigated. Nevertheless, reviewing the preceding investigations shows that a lack of application of a project complexity assessment to support the bid/no-bid decision and consequently the determination of the mark-up percentage is apparent especially in the domain of time. Therefore, to bridge the above-mentioned gap, an investigation with two major steps was planned. In the first step, a model was developed to evaluate the complexity degree of a planned project. In the second step, a model was proposed to support a bid/no-bid decision by contractors, which, in the case of selecting the bid option, will determine the appropriate mark-ups. Additionally, for this purpose and for the presentation of a novel approach to a bid/no-bid decision through complexity analysis of petroleum industry projects, based on a previous research's approach, a three-step methodology, including literature review to recognize complexity factors, experts' judgment to customize the criteria in the petroleum industry, and analysis of historical data to set mark-up spectrums, was programmed. Accordingly, the principal objective of the current study is to investigate the application of complexity measurements in the construction project's tender administration from the contractor's point of view. Due to the above-mentioned lack of studies from the project complexity analysis's point of view for a contractor who intends to offer a bid in a tender, the current study aims to:

1. Develop a model that can take into account all project-inherent complexity factors in a quantitative way, and

2. Propose time/cost mark-ups based on the complexity analysis.

Such decision support system can be a very advantageous model for contractors who are not familiar with some types of projects, may not have enough time to consider all impressive factors, or even tend to have basic estimations besides their available in-house systems. Thus, the main users of this study are construction contractors who define their core business based on the project-based tenders in a competitive environment. Therefore, the main questions of the study are framed as follows:

1. What are the effective criteria to assess the complexity of projects in the context of the petroleum industry?

2. How can the selected criteria be formulated to demonstrate the project complexity in an appropriate manner?

3. What are the quantitative correlations between the project complexity and the decision to propose a bid or no-bid and bid mark-ups?

However, in the following section, the literature of project selection and complexity of projects is reviewed, and project complexity factors in the construction industry are presented. In the next sections, the methodology of the current investigation is described. Finally, the findings are presented.

\section{Literature Review}

The project system is surrounded with dozens of factors that can be leveled into three different areas, as shown in Figure 1. The international, national, and project level parameters are defined by the total situation of an investment in the form of project development [4]. However, this study goes to identify these determinant factors first and 
then aims to convert them into quantitative measures for the tender strategy development phase in the context of the downstream sector of the petroleum industry. The following subsections are divided into three parts. In the first subsection, the project selection in the form of a bid/no-bid decision from the perspective of the contractor is addressed. In the second part, the most related previous investigations are studied to focus on the decision factors, methodology, and findings. The third subsection examines the complexity of various projects, especially in the construction industry; thereafter, the concept of complexity and its various definitions are discussed. In addition, complexity factors and complexity assessment tools are collected from the research literature, and in this way, a framework for providing a quantitative model for evaluating the complexity of construction industry projects is provided.

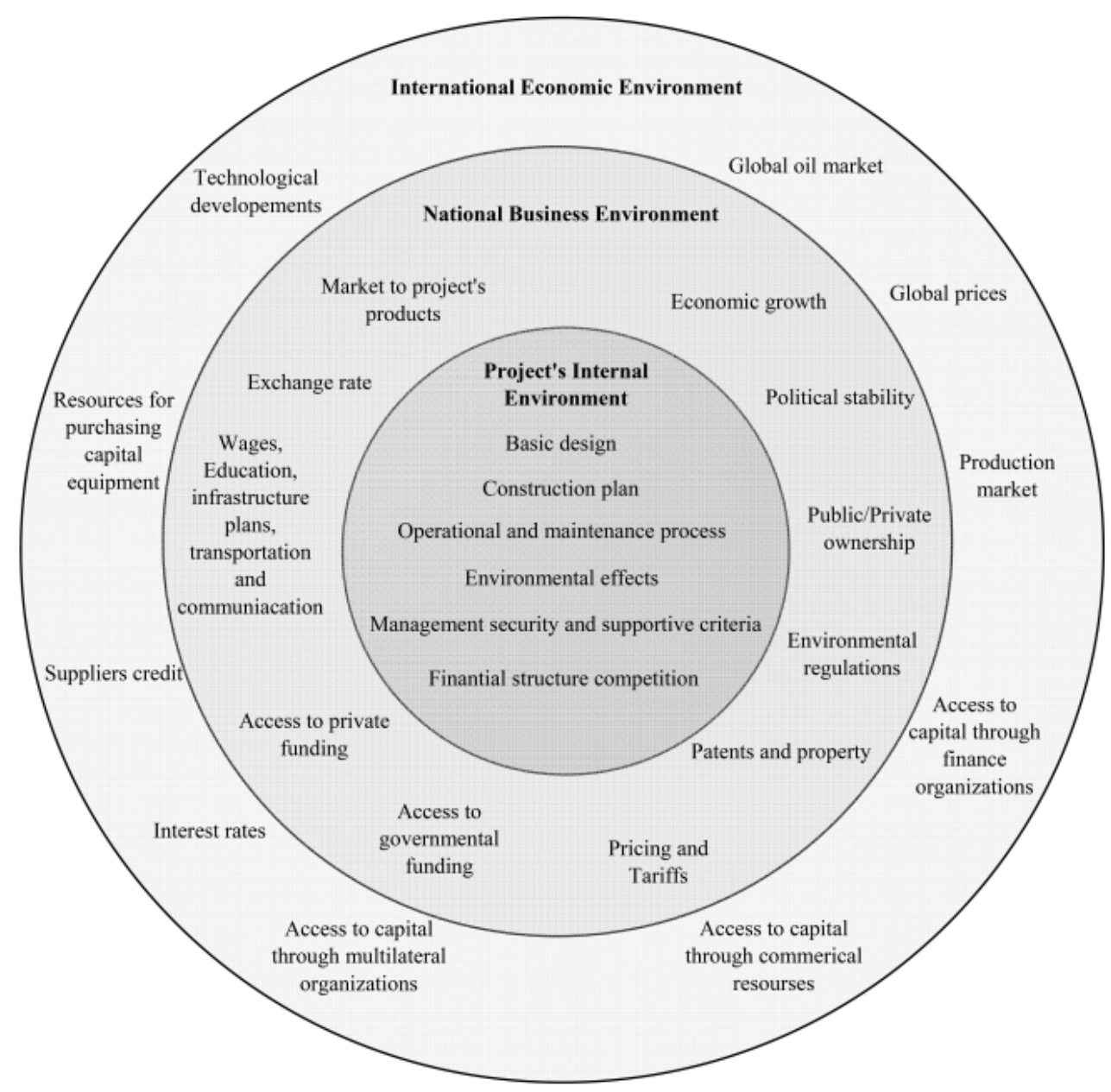

Figure 1. Different levels of characteristics surrounding a construction project (adapted from [4]).

\subsection{Project Selection and Contractor's Tender Strategy}

One of the most crucial decisions regularly exercised by construction contractors is determining whether to bid on a certain project [13-15]. This decision is so complicated due to the complexity and uncertainty surrounding this determination, which is influenced by many factors $[16,17]$. The bidding process is highly complex and unsystematic, requiring numerous factors to be considered simultaneously [18], which have a high degree of complicated interrelations [19-21]. If a contractor opts to bid, the pricing of the bid normally comprises a two-stage formulation process consisting of a baseline cost estimate and subsequent mark-up (e.g., overheads, profit, and risk) [22,23]. Contractors adopt various strategies to enhance their chances of winning work. In 1975, Fine identified several strategies, including random bidding when work levels are low, selective bidding, and 
severely competitive bidding with claim back options within the limits of the contract [24]. Drew offered a model focused on modeling the lowest bid/cost estimate ratio and its regression against the size of construction work, type of construction work, and client type. The bid model offered in this paper shows the effect on a bidding strategy of three of its factors, namely, size and value of the project, type of client, and type of project [12]. Lin et al. adopted a fuzzy logic approach, which helps contractors to make a bid/no-bid decision faster in a timely manner. They indicated that among these factors, those that were related to the clients' characteristics, for example, payment record and size and type of client, were the most important factors [25]. Lee and Chang concentrated on determining the bid mark-up for microtunneling projects that are associated with uncertainties. They developed a decision support system based on survey results, which assists the contractor in selecting an appropriate mark-up [26]. Additionally, Egemen developed an algorithm that can assist contractors reach those decisions by considering different factors. In their decision-making process, they factored in attributes related to the firm itself, to the market, and to the project [11]. Based on a similar rationale, factors influencing bidding behavior were grouped by Drew into those affecting the behavior of contractors as a group, such as market conditions; the individual contractor's behavior, such as contractor size; and the behavior toward the characteristics of the contract, such as type and size of construction work [27]. Flanagan and Norman identified that bidding behavior, in general terms, is likely to be affected by five major factors: the size and value of the project, the construction and managerial complexity required to complete it, the regional market conditions, the current and projected workload of the tenderer, and the type of client and type of project [28]. According to Laryea and Hughes, contractors acknowledge those risks, which they ensure will be paid for [29]; therefore, identifying all relevant risk factors and assessing them appropriately is essential [30]. Additionally, according to Kumar and Raj, the amount of possible upcoming profitable projects in the future, the current financial condition, having qualified material suppliers, project type, experience, and familiarity with the specific work also constitute important influencing factors [9].

\subsection{Previous Models and Methodologies}

Since developing a tender strategy is categorized in decision-making problems, it is not surprising to face a vast spectrum of methodologies, models, and solutions provided in this regard. As one of the first researchers, Ahmad and Minkarah utilized a survey method and questionnaire in the United States to develop a reasoning model for contractors. In the above research, focusing on effective factors of the mark-up size and bid/no-bid decision, the opinions of 400 contractors who were engaged in public sector projects were gathered and prioritized. One of the weaknesses of the findings of this research is the subjectivity of the results so that they are not presented a clear model for the bid/no-bid decision and the size of the mark-up. The effective factors in this study include type of job, need for work, owner, historic profit, degree of hazard, location, degree of difficulty, uncertainty in estimate, and current workload [7]. Additionally, Shash distributed questions among contractors about the factors affecting bid/no-bid in construction projects in the UK. In the first part of the questionnaire, using a Likert scale, the importance of factors in a bid/no-bid decision was determined, and in the second part of the questionnaire, a mark-up size strategy was asked by Shash (1993). The results of this research almost confirm the previous research and again present a conceptual model instead of a practical one. In 1998, Young and Duffield surveyed Australian civil engineering contractors to identify the factors influencing a bid/no-bid decision and improve their mark-up size, and described the tendering practices of Australian construction contractors. The result of this research is a descriptive list of factors that are harvested using a questionnaire and interview. The factors presented in this research are project type, availability of resources and people, experience, need for work, location of a project, desire for a project, need for work, amount of contingency in estimate, experience of a similar project, and likelihood of a winning project [31]. In another attempt, Cagno investigated the factors affecting a mark- 
up size and bid/no-bid decision through a questionnaire using Monte Carlo simulation. In this research based on the analytic hierarchy process (AHP), a model was proposed to predict the probability of winning the tender. This model in the tender stage allows the contractor to evaluate the probability of winning in comparison with other contractors, so it helps contractors to define a strategy in participating in the tender. Evaluation criteria in this model are divided into four general categories: service level, performance, financial conditions, and contractual conditions. Nevertheless, the factors considered in the model are not comprehensive, but the presented model is objective and practical [32]. Dikmen et al. conducted a research on international construction projects in Turkey and developed a decision support tool using a reasoning model. In this research, factors affecting the level of risk, opportunity, and competition were identified, and a decision support tool was developed using a case-based reasoning model (CBR). Experts' judgment were used to prioritize each factor and to identify the lower and upper limits and average values of mark-ups. The introduced framework is an applied model taking into account the general characteristics, risk, and competitive characteristics of projects [33]. Additionally, in the context of Saudi construction projects, Bageis and Fortune identified and prioritized six factors influencing the bid/no-bid decision through 91 received questionnaires, which included the client financial capacity, the prompt payment habit of the client, the project payment system, the clarity of the work and specifications, the project cash flow, and the ability for project execution [34]. Marzouk and Mohamed used a fuzzy fault tree to simulate a bidding decision. In this regard, by reviewing the literature and distributing the questionnaire, 38 factors affecting the contractor's mark-up size were evaluated and prioritized through experts and experienced contractor judgment. Finally, using 15 factors as input, the fuzzy fault tree model was developed and tested by feedback from three contractors. The output of this quantitative model does not include the mark-up size and comprehensiveness input factors [35]. Furthermore, Perera et al., using semistructured interviews and content analysis, identified and weighted the factors influencing the bid/no-bid and mark-up through a questionnaire and the relative importance index. The considered factors in the model are not comprehensive, and the model output does not support the mark-up size decision [36]. Moreover, Kalan and Ozbek in their research developed a decision support tool to assist contractors in bid/no-bid decisions in a construction project. The research methodology of this research has two phases: in the first phase, factors were extracted using a literature review, and in the second phase, using the AHP method, project bidding decision-making tools were developed [8]. However, a comparative study of 12 selected previous research studies in comparison with the current study, to highlight a gap analysis, is shown in Table 1.

Table 1. Comparative study of selected previous research studies and the current study.

\begin{tabular}{|c|c|c|c|c|c|c|c|}
\hline Ref. & $\begin{array}{l}\text { Country/ } \\
\text { Context }\end{array}$ & Methodology & $\begin{array}{c}\text { Tools/ } \\
\text { Techniques }\end{array}$ & $\begin{array}{c}\text { Some of the Factors } \\
\text { Affect Bid/No Bid } \\
\text { Decision }\end{array}$ & $\begin{array}{c}\text { Bid } \\
\text { No Bid }\end{array}$ & $\begin{array}{l}\text { Mark-Up } \\
\text { Size }\end{array}$ & $\begin{array}{c}\text { Decision } \\
\text { Model }\end{array}$ \\
\hline [7] & $\begin{array}{l}\text { USA/general } \\
\text { contractors }\end{array}$ & $\begin{array}{l}\text { In this study, through a } \\
\text { questionnaire, } 400 \text { public } \\
\text { sector contractors were } \\
\text { asked to rate the factors } \\
\text { influencing the bid/no-bid } \\
\text { and mark-up decisions, and } \\
\text { based on this, the author } \\
\text { prioritized and presented } \\
\text { the influential factors. }\end{array}$ & $\begin{array}{l}\text { Reasoning } \\
\text { model }\end{array}$ & $\begin{array}{l}\text { Type of job, need for work, } \\
\text { owner, historic profit, } \\
\text { degree of hazard, location, } \\
\text { degree of difficulty, } \\
\text { uncertainty in estimate, } \\
\text { current workload }\end{array}$ & $\checkmark$ & $\checkmark$ & - \\
\hline [1] & $\begin{array}{l}\text { United king- } \\
\text { dom/construction }\end{array}$ & $\begin{array}{l}\text { The author examined data } \\
\text { from } 85 \text { projects through a } \\
\text { questionnaire and asked the } \\
\text { contractor to prioritize the } \\
\text { factors affecting the } \\
\text { bid/no-bid and the mark-up } \\
\text { extracted from the literature. }\end{array}$ & $\begin{array}{c}\text { Reasoning } \\
\text { model }\end{array}$ & $\begin{array}{l}\text { Degree of difficulty, risk } \\
\text { involved owing to the } \\
\text { nature of the work, } \\
\text { current workload }\end{array}$ & $\checkmark$ & $\checkmark$ & - \\
\hline
\end{tabular}


Table 1. Cont.

\begin{tabular}{|c|c|c|c|c|c|c|c|}
\hline Ref. & $\begin{array}{l}\text { Country/ } \\
\text { Context }\end{array}$ & Methodology & $\begin{array}{c}\text { Tools/ } \\
\text { Techniques }\end{array}$ & $\begin{array}{c}\text { Some of the Factors } \\
\text { Affect Bid/No Bid } \\
\text { Decision }\end{array}$ & $\begin{array}{c}\text { Bid } \\
\text { No Bid }\end{array}$ & $\begin{array}{l}\text { Mark-Up } \\
\text { Size }\end{array}$ & $\begin{array}{c}\text { Decision } \\
\text { Model }\end{array}$ \\
\hline [31] & $\begin{array}{l}\text { Australia/civil } \\
\text { engineering } \\
\text { construction }\end{array}$ & $\begin{array}{l}\text { In this study, in addition to } \\
\text { presenting the factors } \\
\text { influencing bid/no-bid and } \\
\text { mark-up decisions through a } \\
\text { survey questionnaire, } \\
\text { Australian civil engineering } \\
\text { contractors' tendering } \\
\text { practices were described } \\
\text { using interviews. }\end{array}$ & $\begin{array}{l}\text { Reasoning } \\
\text { model }\end{array}$ & $\begin{array}{l}\text { Project type, availability of } \\
\text { resources and people, } \\
\text { experience, need for work, } \\
\text { location of project, desire } \\
\text { for project, amount of } \\
\text { contingency in estimate, } \\
\text { experience in similar } \\
\text { project, likelihood of } \\
\text { winning the project }\end{array}$ & $\checkmark$ & $\checkmark$ & - \\
\hline [32] & $\begin{array}{l}\text { Process plants' } \\
\text { design and } \\
\text { construction }\end{array}$ & $\begin{array}{l}\text { In this study, in addition to } \\
\text { presenting the factors } \\
\text { influencing bid/no-bid and } \\
\text { mark-up decisions through a } \\
\text { survey questionnaire, a } \\
\text { model using a multicriteria } \\
\text { assessment of the probability } \\
\text { of winning was presented. }\end{array}$ & $\begin{array}{l}\text { (MADM) } \\
\text { AHP }\end{array}$ & $\begin{array}{l}\text { Delivery time, technical } \\
\text { assistance, technology } \\
\text { transfer, safety, price, } \\
\text { dependability, process, } \\
\text { technology, terms of } \\
\text { payment, financial } \\
\text { package, liquidated } \\
\text { damages clause, } \\
\text { conformity to tender } \\
\text { documents, contractor } \\
\text { cooperation, utilization of } \\
\text { local vendors }\end{array}$ & $\checkmark$ & $\checkmark$ & $\checkmark$ \\
\hline [34] & $\begin{array}{l}\text { Saudi Arabia/ } \\
\text { construction }\end{array}$ & $\begin{array}{l}\text { The author examined data } \\
\text { from } 91 \text { contractors through } \\
\text { a questionnaire and asked } \\
\text { them to prioritize the factors } \\
\text { affecting the bid/no-bid } \\
\text { decision using the relative } \\
\text { importance index. In order } \\
\text { to be able to select the most } \\
\text { important factors, the } \\
\text { principal component } \\
\text { analysis (PCA) was } \\
\text { conducted. }\end{array}$ & $\begin{array}{c}\text { Principal } \\
\text { component } \\
\text { analysis (PCA) }\end{array}$ & $\begin{array}{l}\text { Client financial capacity, } \\
\text { prompt payment habit of } \\
\text { the client, project payment } \\
\text { system, clarity of the work } \\
\text { and specifications, project } \\
\text { cash flow, ability of } \\
\text { project execution }\end{array}$ & $\checkmark$ & $\checkmark$ & - \\
\hline [37] & $\begin{array}{c}\text { Nigeria/ } \\
\text { construction }\end{array}$ & $\begin{array}{l}\text { Through } 50 \text { questionnaires, } \\
\text { factors affecting the } \\
\text { bid/no-bid decisions were } \\
\text { ranked and presented. }\end{array}$ & $\begin{array}{l}\text { Reasoning } \\
\text { model }\end{array}$ & $\begin{array}{l}\text { Financial capability of } \\
\text { clients, availability of } \\
\text { capital, availability of } \\
\text { materials, fulfilling the "to } \\
\text { tender" condition, chances } \\
\text { of obtaining the job }\end{array}$ & $\checkmark$ & - & - \\
\hline [16] & $\begin{array}{l}\text { Saudi Arabia/ } \\
\text { construction }\end{array}$ & $\begin{array}{l}\text { A total of } 67 \text { questionnaires } \\
\text { were distributed, and } \\
\text { through this, the factors } \\
\text { affecting the bid/no-bid } \\
\text { decision were presented. } \\
\text { These factors by the median } \\
\text { and relative importance } \\
\text { index (RII) were weighted. }\end{array}$ & $\begin{array}{l}\text { Reasoning } \\
\text { model }\end{array}$ & $\begin{array}{l}\text { Size of the job, type of job, } \\
\text { company's strength in the } \\
\text { industry, designer, design } \\
\text { quality, rate of return, } \\
\text { project cash flow }\end{array}$ & $\checkmark$ & - & - \\
\hline [38] & $\begin{array}{c}\text { India/ } \\
\text { construction }\end{array}$ & $\begin{array}{c}\text { The factors influencing the } \\
\text { bid decisions were collected } \\
\text { through a structured } \\
\text { questionnaire survey, and } \\
\text { factors were ranked based } \\
\text { on the survey results, and in } \\
\text { the end, the bid decision } \\
\text { framework using the data } \\
\text { envelopment analysis was } \\
\text { developed. }\end{array}$ & $\begin{array}{l}\text { Data } \\
\text { envelopment } \\
\text { analysis }\end{array}$ & $\begin{array}{l}\text { Amount of possible } \\
\text { upcoming profitable } \\
\text { projects in the future, } \\
\text { current financial condition } \\
\text { of the company, having } \\
\text { qualified material } \\
\text { suppliers, project type, } \\
\text { experience and familiarity } \\
\text { with the specific work }\end{array}$ & $\checkmark$ & - & $\checkmark$ \\
\hline [35] & $\begin{array}{c}\text { Egypt/ } \\
\text { construction }\end{array}$ & $\begin{array}{c}\text { The factors influencing the } \\
\text { bid decisions were collected } \\
\text { through a questionnaire and } \\
\text { used to build a fuzzy fault } \\
\text { tree model to simulate the } \\
\text { bidding decision. }\end{array}$ & Fuzzy fault tree & $\begin{array}{c}\text { Project characteristic, } \\
\text { business benefits, client } \\
\text { characteristic, contract } \\
\text { characteristic, project } \\
\text { finance, contractor } \\
\text { characteristic, firm's } \\
\text { previous experience, } \\
\text { bidding characteristic, } \\
\text { economic characteristic, } \\
\text { competition characteristic }\end{array}$ & $\checkmark$ & - & $\checkmark$ \\
\hline
\end{tabular}


Table 1. Cont.

\begin{tabular}{|c|c|c|c|c|c|c|c|}
\hline Ref. & $\begin{array}{l}\text { Country/ } \\
\text { Context }\end{array}$ & Methodology & $\begin{array}{c}\text { Tools/ } \\
\text { Techniques }\end{array}$ & $\begin{array}{l}\text { Some of the Factors } \\
\text { Affect Bid/No Bid } \\
\text { Decision }\end{array}$ & $\begin{array}{c}\text { Bid } \\
\text { No Bid }\end{array}$ & $\begin{array}{l}\text { Mark-Up } \\
\text { Size }\end{array}$ & $\begin{array}{c}\text { Decision } \\
\text { Model }\end{array}$ \\
\hline [36] & $\begin{array}{l}\text { Sri Lanka/ } \\
\text { infrastructure }\end{array}$ & $\begin{array}{l}\text { Factors influencing the } \\
\text { bid/no-bid and mark-up } \\
\text { decision were identified } \\
\text { from the literature; they } \\
\text { were customized using } \\
\text { semistructured interviews } \\
\text { and content analysis. These } \\
\text { factors were weight-ranked } \\
\text { through a questionnaire and } \\
\text { the relative importance } \\
\text { index. Finally, the results } \\
\text { were tested through a case } \\
\text { study, and recommendations } \\
\text { were presented. }\end{array}$ & $\begin{array}{l}\text { Reasoning } \\
\text { model }\end{array}$ & $\begin{array}{l}\text { Estimated direct costs, } \\
\text { competitiveness of other } \\
\text { bids, type of work, project } \\
\text { duration, ability to predict } \\
\text { a pre-tender estimate }\end{array}$ & $\checkmark$ & $\checkmark$ & - \\
\hline [8] & construction & $\begin{array}{l}\text { The methodology of this } \\
\text { research has two phases. In } \\
\text { the first phase, factors were } \\
\text { extracted using literature } \\
\text { review. In the second phase, } \\
\text { using the AHP method, } \\
\text { construction project bidding } \\
\text { decision-making tools were } \\
\text { developed. }\end{array}$ & $\begin{array}{l}\text { (MADM) } \\
\text { AHP }\end{array}$ & $\begin{array}{c}\text { Current workload; } \\
\text { experience with similar } \\
\text { projects; availability of } \\
\text { equipment, materials, and } \\
\text { human resources; } \\
\text { financial ability; need for } \\
\text { work; technical } \\
\text { know-how; compliance } \\
\text { with the business plan; } \\
\text { project size; project } \\
\text { duration; project location; } \\
\text { project type; contract } \\
\text { condition and type; owner } \\
\text { identity; competition }\end{array}$ & $\checkmark$ & - & $\checkmark$ \\
\hline [10] & $\begin{array}{c}\text { Tanzania/small } \\
\text { building }\end{array}$ & $\begin{array}{l}\text { Data collected through a } \\
\text { survey were analyzed using } \\
\text { SPSS. The } 30 \text { factors } \\
\text { influencing the bid or no-bid } \\
\text { decision, in } 5 \text { groups, were } \\
\text { ranked separately and in } \\
\text { groups. }\end{array}$ & $\begin{array}{l}\text { Reasoning } \\
\text { model }\end{array}$ & $\begin{array}{l}\text { Project characteristic } \\
\text { related, contractor related, } \\
\text { market criteria related, } \\
\text { contract criteria related, } \\
\text { client criteria related }\end{array}$ & $\checkmark$ & - & - \\
\hline $\begin{array}{l}\text { The current } \\
\text { study }\end{array}$ & Iran/petroleum & $\begin{array}{l}\text { Recognition, categorization, } \\
\text { and weighting of the } \\
\text { effective factors on a bid/no } \\
\text { bid decision approach of } \\
\text { complexity analysis of a } \\
\text { project. Determining the } \\
\text { most appropriate mark-up } \\
\text { sizes in the two aspects of } \\
\text { time and cost. }\end{array}$ & $\begin{array}{l}\text { Complexity } \\
\text { analysis }\end{array}$ & $\begin{array}{l}\text { Duration of project, } \\
\text { number of activities, } \\
\text { capital expenditure }\end{array}$ & $\checkmark$ & $\checkmark$ & $\checkmark$ \\
\hline
\end{tabular}

\subsection{Project Complexity Analysis}

The science of complexity is a broad concept that encompasses a number of different scientific fields and industries [39-41]. As it is obvious in the literature of project complexity, projects in the construction industry are one of the most complex and risky projects in various industries [42-44]. Despite the various definitions of project complexity, it is surprising that there is no unanimous definition that all researchers agree on [45-47]. However, project complexity is the feature of a project that makes it difficult to understand, foresee, and keep under control its overall behavior, even when reasonably complete information about the project system is available [45-47]. The main focus of the literature in this area, after defining complexity, is to address the complexity factors. One of the first project classifications based on complexity is made by Gerardo Santana. In this classification, projects were divided into three categories based on complexity and simplicity: normal, complex, and singular [48]. Furthermore, there are dozens of research studies about project complexity factors: Turner and Cochran, in 1993, introduced "the uncertainty in the objectives and methods of achieving projects" as an important factor in project complexity [49]; Baccarini found structural complexity as one of the dimensions of complexity [44]; and William introduced structural complexity and uncertainty in objectives and methods as the two main factors of complexity in projects [50].

Brockmann and Girmscheid divided complexity into five categories: task, society, culture, operation, and cognition complexity [51]; Vidal and Marle introduced a different category of complexity in the four dimensions of project size, project interdependencies, 
project variety, and elements of context [52]; complexity indicators were divided into five categories by Geraldi, Maylor, and Williams: structural complexity, uncertainty, pace, dynamic, and sociopolitical [53]; Ramasesh addressed various factors, such as structural, dynamic, pace, and uncertainty, and introduced a new complexity factor called "unk unks", which is a type of uncertainty that is completely unknown and unpredictable [54]; Qinghua put all the complexity factors in six categories: technological, informational, organizational, environmental, goal, and cultural [55]; Luis Carral et al., in a review of the state of the art, classified different types of complexity into seven general categories: organizational, technological, uncertainty, pace novelty, dynamic, regulative, and sociopolitical [56].

Nevertheless, 68 project complexity factors as general parameters were recognized and categorized by reviewing the literature of project complexity between 1990 and 2020 (Table 2). It should be noted that many of the complexity factors mentioned above cannot be assessed before the tendering stage of the project. Regardless the type of performed classification, turning the complexity factors into a tool for measuring the complexity of projects has been the goal of some studies. In connection with project classification tools through complexity factors, in 2007 a global alliance introduced the Crawford-Ishikura factor table for evaluating roles using seven items of project management complexity factors [57]. A similar tool was jointly published by the International Project Management Association (IPMA) and the Australian Institute of Project Management (AIPM). In this matrix, complexity criteria are organized into 10 groups and 40 complexity subfactors [58]. In 2018, Poveda-Bautista, using the above-mentioned method and the matrix model, measured the complexity of IT projects and categorized projects from low complexity to high complexity [59]. In a relevant study, Dao developed a framework that can be used to assess and manage the project complexity of industrial projects. A framework named Project Complexity Assessment Management Tools (PCAM Tools) was structured with 37 project complexity indicators that belonged to 11 categories from the project management perspective [60]. However, the outline of the literature review in the context of project complexity analysis in this study is summarized in Table 3.

Table 2. General categorization of project complexity factors in the construction industry based on the literature review.

\begin{tabular}{|c|c|c|c|}
\hline No. & Category & Factors & References \\
\hline 1 & \multirow{18}{*}{ Size } & Duration of the project & \multirow{18}{*}[44,48,50,54,61-71]{} \\
\hline 2 & & Number of deliverables/disciplines & \\
\hline 3 & & Number of activities & \\
\hline 4 & & Largeness of capital investment & \\
\hline 5 & & Number of project management methods and tools applied & \\
\hline 6 & & Number of different occupational specializations & \\
\hline 7 & & Number of stakeholders & \\
\hline 8 & & Largeness of scope (number of components, etc.) & \\
\hline 9 & & Number of structures/groups/teams to be coordinated & \\
\hline 10 & & Number of objectives or goals & \\
\hline 11 & & Number of investors & \\
\hline 12 & & Staff quantity & \\
\hline 13 & & Number of hierarchical levels & \\
\hline 14 & & Number of information systems & \\
\hline 15 & & Number of joint-venture partners & \\
\hline 16 & & Number of funding phases & \\
\hline 17 & & Total number of permits & \\
\hline 18 & & Size of project team & \\
\hline
\end{tabular}


Table 2. Cont.

\begin{tabular}{|c|c|c|c|}
\hline No. & Category & Factors & References \\
\hline 19 & \multirow{15}{*}{ Context } & Degree of project flexibility (in scope, process, organization) & \multirow{15}{*}[52,56,60-62,70-74]{} \\
\hline 20 & & Repetition of similar type of projects & \\
\hline 21 & & Internal politics issue (ambiguity, hidden information) & \\
\hline 22 & & Cultural configuration & \\
\hline 23 & & Contract specifications & \\
\hline 24 & & New laws and regulations & \\
\hline 25 & & Local laws and regulations & \\
\hline 26 & & Number of organizational risks & \\
\hline 27 & & Geological condition/difficulty of location & \\
\hline 28 & & External politics issue & \\
\hline 29 & & Impact on the environment & \\
\hline 30 & & Form of contract & \\
\hline 31 & & Organizational degree of innovation & \\
\hline 32 & & Lack of experience with partners & \\
\hline 33 & & Government environmental regulations & \\
\hline 34 & \multirow{11}{*}{ Diversity } & Variety of financial resources & \multirow{11}{*}{$\begin{array}{c}{[48,50,52,62,64,66-} \\
68,70,73,75-79]\end{array}$} \\
\hline 35 & & Diversity of tasks & \\
\hline 36 & & Diversity of staff (experience, social span) & \\
\hline 37 & & Variety of stakeholders & \\
\hline 38 & & Cultural variety & \\
\hline 39 & & Number of different languages & \\
\hline 40 & & Variety of technologies used during the project & \\
\hline 41 & & Multiple participating countries/location & \\
\hline 42 & & Geographic location of the stakeholders & \\
\hline 43 & & Weather conditions & \\
\hline 44 & & Number of external stakeholders & \\
\hline 45 & \multirow{3}{*}{ Connectivity } & Number of interfaces in the project organization & \multirow{3}{*}[52,62,63,77]{} \\
\hline 46 & & Percentage of design completed at the start of construction & \\
\hline 47 & & Communication between different parts of the organization & \\
\hline 48 & \multirow{11}{*}{ Autonomy } & Availability of people, material, and any resources due to sharing & \multirow{11}{*}{$\begin{array}{c}{[44,50,52,62-} \\
64,70,73,74,77]\end{array}$} \\
\hline 49 & & Team/partner cooperation and communication & \\
\hline 50 & & Dynamic and evolving team structure & \\
\hline 51 & & Interdependencies between sites, departments, and companies & \\
\hline 52 & & Interdependencies of objectives/interests & \\
\hline 48 & & Interdependencies between actors & \\
\hline 53 & & Percentage of PM staff who work on the project vs. planned staff & \\
\hline 54 & & Resource and raw material interdependence & \\
\hline 55 & & Dependencies between schedules & \\
\hline 56 & & Number of governmental people who are involved in projects & \\
\hline 53 & & Process interdependence & \\
\hline
\end{tabular}


Table 2. Cont.

\begin{tabular}{|c|c|c|c|}
\hline No. & Category & Factors & References \\
\hline 54 & & Dependencies between schedules & \\
\hline 55 & & Interdependence between components of the product & \\
\hline 56 & & Level of interrelation of between phases & \\
\hline 57 & \multirow{7}{*}{ Belonging } & Cost restraint (cost and financing) & \multirow{7}{*}[52,56,62,65,67,74]{} \\
\hline 58 & & Requirement specifications & \\
\hline 59 & & Technical capability of team & \\
\hline 60 & & Technological newness of the project & \\
\hline 61 & & Use of a technology that has not yet been fully developed & \\
\hline 62 & & Equipment specifications & \\
\hline 63 & & Specifications of systems & \\
\hline 64 & \multirow{5}{*}{ Emergence } & Dynamics of the task activities & \multirow{5}{*}[49,50,62,67,70,72,74,76,80]{} \\
\hline 65 & & Uncertainties of scope & \\
\hline 66 & & Uncertainty and clarity of objectives or goals & \\
\hline 67 & & Uncertainty in technical methods & \\
\hline 68 & & Information uncertainty & \\
\hline
\end{tabular}

Table 3. Overview of the selected papers of literature focused on project complexity.

\begin{tabular}{|c|c|c|c|c|c|}
\hline Ref. & Paper Type & Industry & Project Complexity Definition & $\begin{array}{l}\text { Categories and Factors of } \\
\text { Complexity/Characteristic }\end{array}$ & $\begin{array}{l}\text { Cited by } \\
\text { (Google Scholar on } \\
\text { 20 February 2021) }\end{array}$ \\
\hline [49] & Conceptual & General & $\begin{array}{l}\text { Degree of whether the goals and } \\
\text { methods of achieving them are } \\
\text { well defined }\end{array}$ & Uncertainty of objectives/uncertainty of methods & 785 \\
\hline [44] & Review & Construction & $\begin{array}{l}\text { Project complexity consisting of } \\
\text { many varied interrelated parts } \\
\text { can be operationalized in terms } \\
\text { of "differentiation and } \\
\text { interdependency or connectivity" }\end{array}$ & Organizational/technological & 1518 \\
\hline [50] & Review & General & - & $\begin{array}{l}\text { Structural (number of elements, interdependence } \\
\text { of elements), uncertainty in goals, uncertainty } \\
\text { in methods }\end{array}$ & 993 \\
\hline [53] & Systematic review & General & $\begin{array}{l}\text { Provide definitions of previous } \\
\text { research }\end{array}$ & $\begin{array}{l}\text { Structural, uncertainty, dynamics, } \\
\text { pace, sociopolitical }\end{array}$ & 480 \\
\hline [71] & Empirical study & Construction & $\begin{array}{l}\text { The complexity of building } \\
\text { projects defined as a } \\
\text { characteristic that are } \\
\text { complicated, multifaceted, and } \\
\text { composed of many } \\
\text { interconnected parts }\end{array}$ & $\begin{array}{l}\text { Building structure and function, construction } \\
\text { method, urgency of project schedule, project size, } \\
\text { geological condition, neighboring environment }\end{array}$ & 161 \\
\hline [65] & Report & General & $\begin{array}{l}\text { Complexity has different } \\
\text { meanings for different people } \\
\text { and in different organizations }\end{array}$ & $\begin{array}{l}\text { Multiple stakeholders; ambiguity of project } \\
\text { features, resources, phases, etc.; significant } \\
\text { politics; authority influences; unknown project } \\
\text { features, resources, phases, etc.; dynamic } \\
\text { (changing) project governance; significant } \\
\text { external influences; use of a technology that is } \\
\text { new to the organization; use of a technology that } \\
\text { has not yet been fully developed; significant } \\
\text { internal interpersonal or social influences; highly } \\
\text { regulated environment; project duration exceeds } \\
\text { the cycle of relevant technologies }\end{array}$ & 5 \\
\hline [81] & Case study & Construction & $\begin{array}{c}\text { Consisting of many varied } \\
\text { interrelated parts and has } \\
\text { dynamic and emerging features }\end{array}$ & Task complexity, organizational complexity & 129 \\
\hline [55] & Case study & Construction & - & $\begin{array}{l}\text { A total of } 28 \text { factors divided into } 6 \text { categories } \\
\text { include: technological, organizational, goal, } \\
\text { environmental, cultural, informational }\end{array}$ & 177 \\
\hline [70] & Empirical study & $\begin{array}{l}\text { Construction, IT, } \\
\text { textile, automobile, } \\
\text { R\&D }\end{array}$ & - & $\begin{array}{l}\text { This study focused on organizational complexity: } \\
\text { project size, project variety, interdependencies } \\
\text { within the project, elements of context }\end{array}$ & 183 \\
\hline
\end{tabular}


Table 3. Cont.

\begin{tabular}{|c|c|c|c|c|c|}
\hline Ref. & Paper Type & Industry & Project Complexity Definition & $\begin{array}{l}\text { Categories and Factors of } \\
\text { Complexity/Characteristic }\end{array}$ & $\begin{array}{c}\text { Cited by } \\
\text { (Google Scholar on } \\
20 \text { February 2021) }\end{array}$ \\
\hline [62] & Systematic review & General & $\begin{array}{l}\text { Define project complexity as } \\
\text { an intricate arrangement of the } \\
\text { varied interrelated parts in which } \\
\text { the elements can change } \\
\text { and evolve constantly with effect } \\
\text { on the project objectives }\end{array}$ & $\begin{array}{l}\text { From the PMI view, this study divided the } \\
\text { complexity factors into } 9 \text { categories, which } \\
\text { include: content, context, organizational, } \\
\text { interdependencies, technology, information, } \\
\text { product or service, client, external environment }\end{array}$ & 172 \\
\hline [63] & Empirical study & Construction & $\begin{array}{l}\text { Project complexity is the degree } \\
\text { of interrelatedness between } \\
\text { project attributes and interfaces } \\
\text { and their consequential impact } \\
\text { on predictability } \\
\text { and functionality }\end{array}$ & $\begin{array}{l}\text { This study classified } 10 \text { complexity indicators into } \\
9 \text { groups, including: interfaces, scope definition, } \\
\text { project resources, design and technology, scope } \\
\text { definition, location, governance, project resources, } \\
\text { stakeholder management }\end{array}$ & 48 \\
\hline [64] & Empirical study & Construction & - & $\begin{array}{c}\text { This study classified } 28 \text { complexity factors into } \\
3 \text { categories: technological, } \\
\text { organizational, environmental }\end{array}$ & 4 \\
\hline [82] & Empirical study & General & $\begin{array}{l}\text { According to a previous study } \\
\text { conducted in } 2011\end{array}$ & Structural, sociopolitical, emergent & 60 \\
\hline [56] & $\begin{array}{l}\text { Review of the } \\
\text { state of the } \\
\text { art/case study }\end{array}$ & engineering & - & $\begin{array}{l}\text { This research focuses on the organizational and } \\
\text { technological complexity of a shipbuilding project } \\
\text { and evaluates the project complexity according to } \\
\text { the project definition, design, and } \\
\text { production phases }\end{array}$ & - \\
\hline [83] & Empirical study & General & $\begin{array}{l}\text { Project complexity is the } \\
\text { interrelatedness of elements } \\
\text { causing an emergent nature of } \\
\text { the project and challenging the } \\
\text { project management }\end{array}$ & $\begin{array}{l}\text { Element, political, diversity, difficulty, goals, } \\
\text { ambiguity, control, method, rigid, } \\
\text { trust, experience }\end{array}$ & - \\
\hline$[84]$ & Empirical study & Construction & - & $\begin{array}{l}\text { This study classified } 27 \text { complexity indicators into } \\
11 \text { groups, including: stakeholder, management, } \\
\text { governance, fiscal planning, quality, legal, } \\
\text { interfaces, execution target, design and } \\
\text { technology, location, scope definition, } \\
\text { project resources }\end{array}$ & - \\
\hline
\end{tabular}

\section{Research Methodology}

The different steps of the research process, which were adopted to achieve the project objectives are summarized in the following paragraphs:

Step 1. The first stage of step 1 in the current investigation was the study and recognition of the complexity factors inquired by previous researchers. At this stage, by examining English language research between 1990 and 2020 in scientific databases, more than 150 complexity factors related to different industries were recognized. It is worth mentioning that project complexity has been studied in different project-based industries, such as information and communications technology (ICT), and taking their projects' raised factors into account in the construction industry can enrich investigations of this industry. In the second stage, to identify and select the most compatible factors with downstream petroleum projects in Iran, the extracted factors were judged by six experts from this industry who had experience in cooperating in several complex projects in the construction industry. The above experts were selected based on one of the following factors: professional person with more than 10 years' experience in projects in the downstream sector as client, consultant, or contractor, and/or academic person expert in the field of construction management, contract administration, or petroleum projects (Table 4). It should be noted that these experts were chosen in such a way that has no relation to 139 projects used to develop the model.

Table 4. Descriptive data and demography of the selected experts.

\begin{tabular}{|c|c|c|c|c|c|c|c|c|c|c|c|}
\hline \multirow{2}{*}{$\begin{array}{c}\text { Area of } \\
\text { Expertise }\end{array}$} & \multirow{2}{*}{$\begin{array}{l}\text { Number of } \\
\text { Experts }\end{array}$} & \multicolumn{3}{|c|}{ Age } & \multirow{2}{*}{$\begin{array}{c}\text { Average Years of Work } \\
\text { Experience }\end{array}$} & \multicolumn{3}{|c|}{ Area of Profession } & \multicolumn{3}{|c|}{ Education } \\
\hline & & $35-40$ & $40-45$ & $>45$ & & Client & Contractor & Consultant & Ph.D. & M.S. & B.S. \\
\hline Academic & 2 & & $2(33.5 \%)$ & & 11.8 & - & - & - & 2 & - & - \\
\hline Professional & 4 & $1(16.5 \%)$ & & $3(50 \%)$ & 18.2 & 1 & 1 & 2 & 1 & 2 & 1 \\
\hline
\end{tabular}


Step 2. These recognized factors were refined through two processes: first, a raw list of extracted factors was delivered to experts for review, in which 68 related and compatible parameters within the construction industry were determined based on the content analysis of the received questionnaires, and second, the 68 revised, improved, and categorized factors by the research team, considering projects in the downstream sector, were resent to the experts for final comments. The result of this step led to the identification and categorization of 54 complexity factors, which can be considered the most effective factors of complexity recognition in projects in the petroleum downstream sector in Iran. In the next stage, in order to analyze complexity factors and determine the criteria weightings, related references, and their metrics, a two-round reciprocal Delphi technique was used. It is worth mentioning that since the complexity factors may have countereffects on each other, the determination of such dependencies can be very helpful in ranking and weighting them by experts. Therefore, before this stage, using a comparative matrix, the interdependency of criteria was measured relative to each other to have the lowest interdependency (Figure 2). To have the above interdependency of 54 criteria, prior to the Delphi process, the experts were asked to review the factors and mark their counterimpacts on each other with 1 indicating high and 0 indicating low. The final result shown in Figure 2 is the average of opinions of six experts. However, the result of this step was a quantitative model for measuring the complexity of projects based on their characteristics. The input of this model is the estimation of the metrics of a given project and, subsequently, the calculation of its complexity. To rate each project based on the complexity factors, Equation (1), which includes a simple average in each category and a weighted average of all subcategories, was used:

$$
\operatorname{PCI}\left(P_{t}\right)=\frac{\sum_{i=1}^{a} p w_{i j} \sum_{j=1}^{b}\left(k_{i} \cdot w_{j}\right) / \mathrm{b}}{a}
$$

where:

$P C I$ is the overall complexity index of the $t$-th project $\left(P_{t}\right)$;

$p w_{i}$ is the percentage weight of the $i$-th category of $k, i=\{1,2, \ldots, a=6\}$;

$k_{i}$ is the $i$-th main category of factors;

$w_{j}$ is the weight of the $j$-th factor in each main category, $j=\{1,2, \ldots, b\}$; and

$b$ is the number of factors in each of the six main categories.

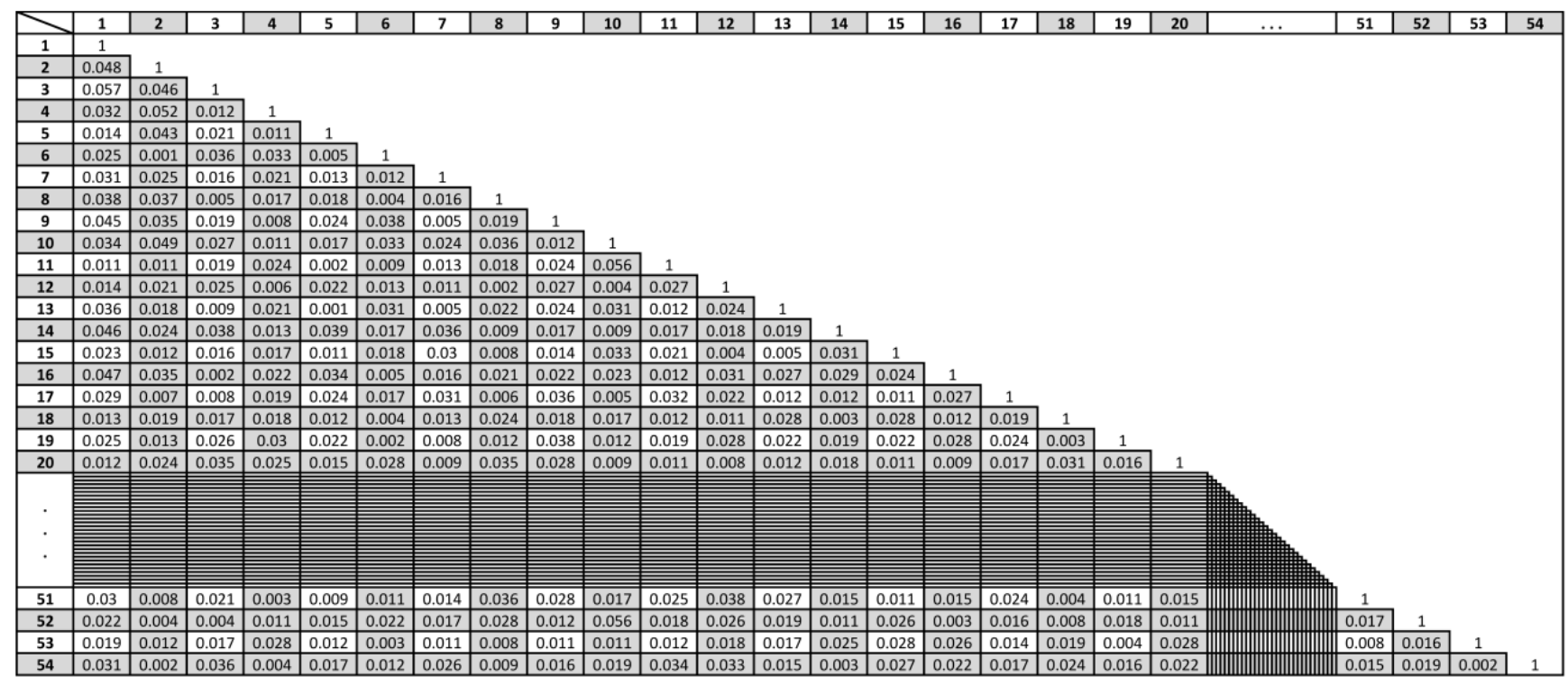

Figure 2. Measurement of the interdependency of 54 factors. 
Step 3. To respond to the next question of the study, relative mark-ups had to be estimated in order to prepare the contractor's proposals in a logical manner. Since the main aspects of the contractor's proposal in a hard bid of the traditional system are price and schedule, the mark-ups were defined in the two categories of cost and time. Therefore, in this step and to offer a formula for calculating the cost and time mark-ups of the proposal as the main risk mitigation factors of the agreement for the contractor, nonlinear regression analysis of successful previous projects was employed. Regression analysis, as a credible method for recognizing the relationship between variables and discovering trends, is frequently utilized for tender analysis in the construction industry [85-88]. Regression analysis reveals how a variable or a set of parameters as input, complexity factors in this study, affect an output, time/cost mark-ups [89]. Disclosure of relationships between studied parameters provides the trend prediction ability and basic knowledge of decision making [90]. There is a correlation of variables in the regression measures of both strength as the severity of dependence and direction as the orientation of relationship [91].

For this purpose, data from 139 previous implemented projects in the petroleum industry in Iran were gathered, and $80 \%$ of them (111) were applied to model development, and the remaining 28 projects ( $20 \%$ ) were considered to test and assess the model. The data from the 139 previous projects were stacked up from eight major Iranian contractors who were taken into account as major companies with first rank (out of five) in the national contractor ranking system. As shown in Table 5, the available contracts can fall into one of the six categories of development projects in oil refineries, gas processing units, petrochemical plants, pipeline, oil/gas storage tanks, and fuel facilities. All of the above projects are recognized as large projects, which means that they are based on the client's estimation of cost of more than USD 500 million. Based on the complexity analysis of 111 previously implemented projects and mapping them with the favorable profit margins, definitely from the contractor's viewpoint, the ranges of mark-ups were proposed in the areas of cost and time. Therefore, the input of the model in this step is the project complexity index, and the output is the cost and time mark-ups for the contractor's proposal, which will be submitted to the client. Finally, to assess the proposed model, data from 28 downstream projects were considered as test data. These projects were selected in such a way as to include all types of projects illustrated in Table 5 in a balanced method. Actual data from the above projects were fed to the model, and the calculated mark-ups were compared with the contractors' opinion. The results show that the deviation of the presented model from the contractors' average opinions is $75.36 \%$ and $74.67 \%$ for cost and time, respectively. Figure 3, demonstrates the different steps of the research methodology.

Table 5. Historical data from 139 projects employed to develop and assess the proposed model.

\begin{tabular}{|c|c|c|c|c|c|c|c|}
\hline \multirow{2}{*}{ Contractors } & \multicolumn{6}{|c|}{ Types of Projects } & \multirow{2}{*}{ Total } \\
\hline & Oil Refinery & Gas Processing & Petrochemical Plant & Pipeline & Oil/Gas Storage Tanks & Fuel Facilities & \\
\hline $\mathrm{C} 1$ & 2 & 2 & 2 & 3 & 8 & 4 & 21 \\
\hline $\mathrm{C} 2$ & 0 & 2 & 1 & 3 & 4 & 7 & 17 \\
\hline C3 & 1 & 0 & 2 & 1 & 2 & 4 & 10 \\
\hline $\mathrm{C} 4$ & 2 & 2 & 1 & 3 & 7 & 6 & 21 \\
\hline C5 & 2 & 2 & 2 & 3 & 5 & 7 & 21 \\
\hline C6 & 1 & 2 & 0 & 2 & 7 & 5 & 17 \\
\hline $\mathrm{C} 7$ & 1 & 0 & 2 & 1 & 5 & 4 & 13 \\
\hline $\mathrm{C} 8$ & 2 & 2 & 2 & 3 & 4 & 6 & 19 \\
\hline Total & 11 & 12 & 12 & 19 & 42 & 43 & 139 \\
\hline
\end{tabular}


Step 1.

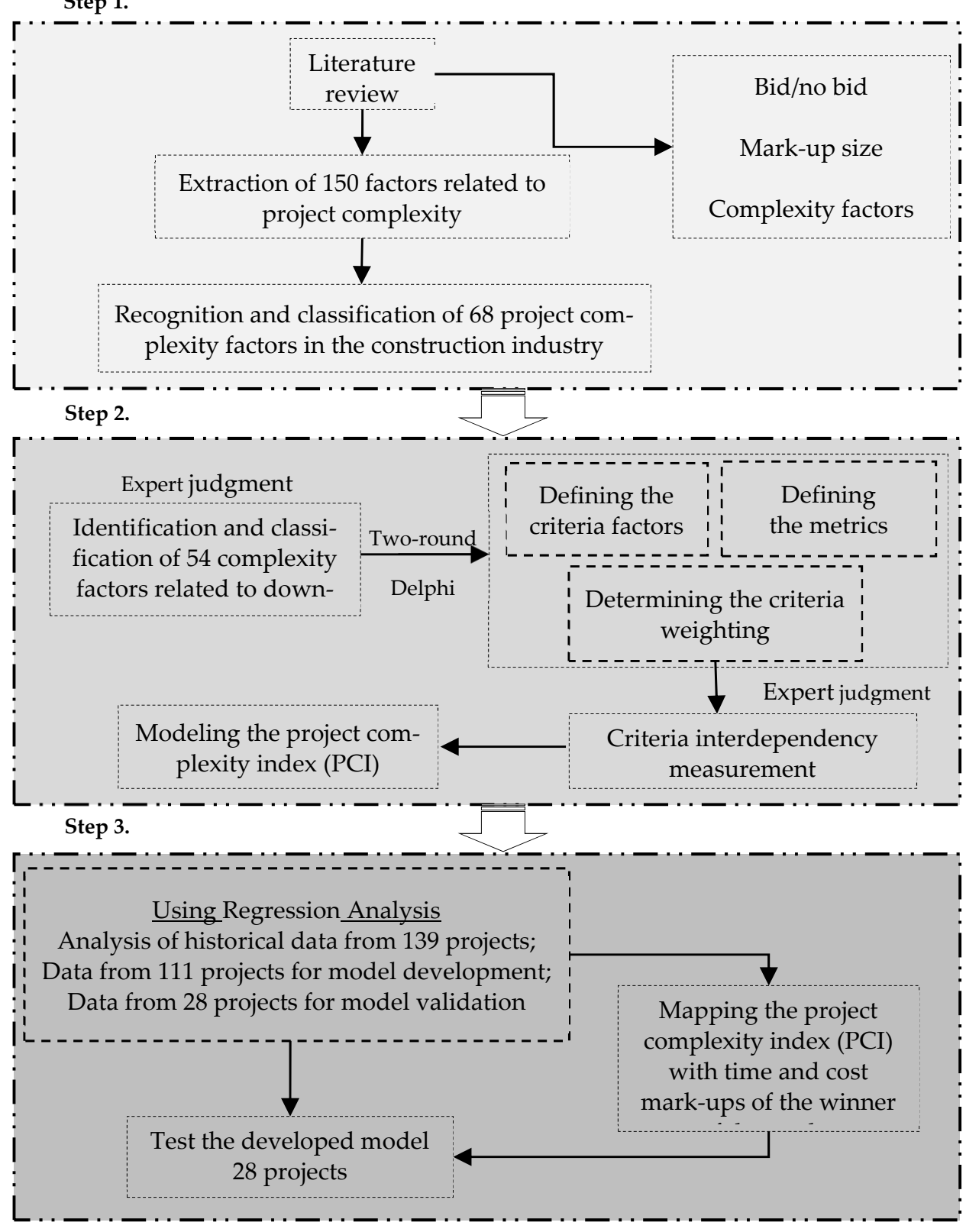

Figure 3. Research methodology.

\section{Data Analysis and Results}

\subsection{Project Complexity Index (PCI)}

As mentioned earlier, project complexity can be measured with some factors investigated in previous research. Since projects in the construction industry can be defined in a wide range, from housing to buildings and industrial projects, it is important to identify and to tailor-make the effective factors in a specified category. The scope of this study included downstream projects in the petroleum industry, and therefore, the effective factors of project complexity were investigated with the main characteristics of these projects. The extracted factors from the literature review using experts' judgment were purified, customized, and categorized based on the requirements of the downstream projects in the petroleum industry. In this process, a total of 54 factors were identified, in which 14 of them were specifically proposed by the experts (Table 6). Subsequently, the above recognized factors were analyzed in a two-round Delphi method, and the following were determined: 
1. To improve the precision of the complexity calculations based on a weighted method, the factors were classified into 6 main categories.

2. Obviously, the main categories had no equal significance in project complexity calculations, and therefore, the percentage weight of each category was determined. Additionally, to have more precise results, the importance of each factor was characterized independently.

3. To score each factor against project complexity, the document that should be considered main reference was specified. The usage of the same documents for factors' complexity calculation is very crucial, because in this case, the comparison between different projects will be realistic.

4. Having a reasonable quantitative range for each of the factors was another parameter that should be ascertained. For this purpose, a metric, graded from 1 to 10 , was defined for each factor, based on which the factor will be quantified.

Table 6. Effective factors on the project complexity index (PCI), their weights, references, and metrics.

\begin{tabular}{|c|c|c|c|c|c|c|}
\hline $\begin{array}{c}\text { Main } \\
\text { Category }\end{array}$ & $\begin{array}{c}\text { Percentage } \\
\text { Weight }\left(p w_{i}\right)\end{array}$ & Factors & Weight $\left(w_{j}\right)$ & Reference & $\begin{array}{c}\text { Metrics Spectrum } \\
\text { (Low Complexity: 1; High Complexity: 10) }\end{array}$ & Description \\
\hline \multirow{11}{*}{ 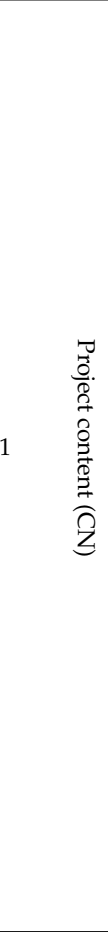 } & \multirow{11}{*}{0.29} & $\begin{array}{l}\text { The duration of the } \\
\text { project }\end{array}$ & 0.800 & $\begin{array}{l}\text { Project time } \\
\text { estimation }\end{array}$ & $\begin{array}{l}\text { Equal to or less than } 6 \text { months: } 1 \\
\text { More than } 36 \text { months: } 10\end{array}$ & - \\
\hline & & The number of activities & 0.787 & $\begin{array}{c}\text { Project } \\
\text { schedule }\end{array}$ & $\begin{array}{l}\text { Equal to or less than } 3000 \text { activities: } 1 \\
\text { More than } 10,000 \text { activities: } 10\end{array}$ & - \\
\hline & & $\begin{array}{l}\text { The capital expenditure } \\
\text { (CAPEX) }\end{array}$ & 0.812 & $\begin{array}{l}\text { Project cost } \\
\text { estimation }\end{array}$ & $\begin{array}{l}\text { Equal to or less than USD } 500 \text { million: } 1 \\
\text { More than USD } 4 \text { billion: } 10\end{array}$ & - \\
\hline & & $\begin{array}{l}\text { The number of overall } \\
\text { human resources } \\
\text { required in the } \\
\text { implementation phase }\end{array}$ & 0.800 & Project plan & $\begin{array}{l}\text { Equal to or less than } 500 \text { persons: } 1 \\
\text { More than } 5000 \text { persons: } 10\end{array}$ & - \\
\hline & & $\begin{array}{l}\text { The number of critical } \\
\text { objectives of the project }\end{array}$ & 0.837 & Project plan & $\begin{array}{l}\text { Equal to or less than } 3 \text { main objectives: } 1 \\
\text { More than } 10 \text { main objectives: } 10\end{array}$ & - \\
\hline & & $\begin{array}{l}\text { The probability of scope } \\
\text { creep }\end{array}$ & 0.950 & $\begin{array}{l}\text { Project risk } \\
\text { plan }\end{array}$ & $\begin{array}{l}\text { Low probability: } 1 \\
\text { High probability: } 10\end{array}$ & $\begin{array}{l}\text { Based on } \\
\text { previous } \\
\text { experience }\end{array}$ \\
\hline & & $\begin{array}{c}\text { The number of required } \\
\text { occupational } \\
\text { specialized areas }\end{array}$ & 0.850 & $\begin{array}{l}\text { Project basic } \\
\text { design }\end{array}$ & $\begin{array}{l}\text { Equal to or less than } 5 \text { areas: } 1 \\
\text { More than } 12 \text { areas: } 10\end{array}$ & - \\
\hline & & $\begin{array}{c}\text { The probability of } \\
\text { change of project } \\
\text { objectives }\end{array}$ & 0.962 & $\begin{array}{l}\text { Project risk } \\
\text { plan }\end{array}$ & $\begin{array}{l}\text { Low probability: } 1 \\
\text { High probability: } 10\end{array}$ & $\begin{array}{l}\text { Based on } \\
\text { previous } \\
\text { experience }\end{array}$ \\
\hline & & $\begin{array}{l}\text { The implementation } \\
\text { intricacy }\end{array}$ & 0.837 & Project design & $\begin{array}{l}\text { Low intricacy: } 1 \\
\text { High intricacy: } 10\end{array}$ & $\begin{array}{l}\text { Based on } \\
\text { previous } \\
\text { experience }\end{array}$ \\
\hline & & $\begin{array}{l}\text { The importance of } \\
\text { project completion date }\end{array}$ & 0.737 & Contract & $\begin{array}{l}\text { Low importance: } 1 \\
\text { High importance: } 10\end{array}$ & $\begin{array}{l}\text { Changeability of } \\
\text { timing }\end{array}$ \\
\hline & & $\begin{array}{l}\text { The level of design } \\
\text { errors }\end{array}$ & 0.787 & $\begin{array}{l}\text { Project basic } \\
\text { design }\end{array}$ & $\begin{array}{l}\text { Low number of errors: } 1 \\
\text { High number of errors: } 10\end{array}$ & $\begin{array}{l}\text { Basic design } \\
\text { done by client } \\
\text { organization }\end{array}$ \\
\hline \multirow{7}{*}{ ت્ق. } & \multirow{7}{*}{0.14} & $\begin{array}{l}\text { The number of } \\
\text { investors }\end{array}$ & 0.837 & Project plan & $\begin{array}{l}\text { Equal to or less than } 1 \text { investor: } 1 \\
\text { More than } 8 \text { investors: } 10\end{array}$ & - \\
\hline & & $\begin{array}{l}\text { The number of key } \\
\text { stakeholders }\end{array}$ & 0.987 & Project plan & $\begin{array}{l}\text { Equal to or less than } 3 \text { key stakeholders: } 1 \\
\text { More than } 8 \text { key stakeholders: } 10\end{array}$ & - \\
\hline & & $\begin{array}{l}\text { The precision of } \\
\text { primary studies }\end{array}$ & 0.850 & $\begin{array}{l}\text { Project basic } \\
\text { design }\end{array}$ & $\begin{array}{l}\text { High precision: } 1 \\
\text { Low precision: } 10\end{array}$ & $\begin{array}{c}\text { Primary studies } \\
\text { done by the } \\
\text { client } \\
\text { organization }\end{array}$ \\
\hline & & $\begin{array}{l}\text { The impact of the } \\
\text { internal policies of the } \\
\text { client on the project } \\
\text { implementation process }\end{array}$ & 0.750 & $\begin{array}{l}\text { Investigating } \\
\text { the client } \\
\text { organization }\end{array}$ & $\begin{array}{l}\text { Low level of interference: } 1 \\
\text { High level of interference: } 10\end{array}$ & - \\
\hline & & $\begin{array}{l}\text { The project contract } \\
\text { pricing method }\end{array}$ & 0.762 & $\begin{array}{c}\text { Project } \\
\text { document }\end{array}$ & $\begin{array}{l}\text { Cost reimbursable }=1 \\
\text { Time and material }=5 \\
\text { Fixed price }=10\end{array}$ & - \\
\hline & & $\begin{array}{l}\text { The accessibility of key } \\
\text { stakeholders }\end{array}$ & 0.825 & Project plan & $\begin{array}{l}\text { High level of accessibility: } 1 \\
\text { Low level of accessibility: } 10\end{array}$ & $\begin{array}{l}\text { Availability of } \\
\text { stakeholders for } \\
\text { the meeting }\end{array}$ \\
\hline & & $\begin{array}{l}\text { The project financing } \\
\text { method }\end{array}$ & 0.700 & $\begin{array}{c}\text { Project } \\
\text { document }\end{array}$ & $\begin{array}{l}\text { Corporate finance }=1 \\
\text { Finance }=5 \\
\text { Project finance }=10\end{array}$ & - \\
\hline
\end{tabular}


Table 6. Cont.

\begin{tabular}{|c|c|c|c|c|c|c|c|}
\hline & gory & $\begin{array}{c}\text { Percentage } \\
\text { Weight }\left(p w_{i}\right)\end{array}$ & Factors & Weight $\left(w_{j}\right)$ & Reference & $\begin{array}{c}\text { Metrics Spectrum } \\
\text { (Low Complexity: 1; High Complexity: 10) }\end{array}$ & Description \\
\hline \multirow{4}{*}{3} & \multirow{4}{*}{ 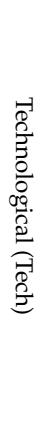 } & \multirow{4}{*}{0.18} & $\begin{array}{l}\text { The accessibility of } \\
\text { technical human } \\
\text { resources locally }\end{array}$ & 0.775 & $\begin{array}{l}\text { Investigating } \\
\text { the local } \\
\text { suppliers }\end{array}$ & $\begin{array}{l}\text { Low accessibility: } 1 \\
\text { High accessibility: } 10\end{array}$ & $\begin{array}{l}\text { What percentage } \\
\text { of the total need } \\
\text { will be met by } \\
\text { local resources }\end{array}$ \\
\hline & & & $\begin{array}{c}\text { The technological } \\
\text { newness level of the } \\
\text { project }\end{array}$ & 0.975 & Project plan & $\begin{array}{l}\text { Low level of newness: } 1 \\
\text { High level of newness: } 10\end{array}$ & $\begin{array}{c}\text { Based on } \\
\text { previous } \\
\text { experience in } \\
\text { using technology }\end{array}$ \\
\hline & & & $\begin{array}{l}\text { The technological level } \\
\text { of the required } \\
\text { equipment }\end{array}$ & 0.925 & $\begin{array}{l}\text { Project basic } \\
\text { design }\end{array}$ & $\begin{array}{l}\text { Low level of technology: } 1 \\
\text { High level of technology: } 10\end{array}$ & - \\
\hline & & & $\begin{array}{c}\text { The availability of the } \\
\text { project technologies } \\
\text { locally }\end{array}$ & 0.812 & $\begin{array}{l}\text { Investigating } \\
\text { the local } \\
\text { weather } \\
\text { records }\end{array}$ & $\begin{array}{l}\text { High level of availability: } 1 \\
\text { Low level of availability: } 10\end{array}$ & - \\
\hline \multirow{4}{*}{4} & \multirow{4}{*}{ 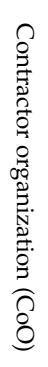 } & \multirow{4}{*}{0.09} & $\begin{array}{l}\text { The previous experience } \\
\text { with the client }\end{array}$ & 0.912 & $\begin{array}{l}\text { Internal } \\
\text { documents }\end{array}$ & $\begin{array}{l}\text { Equal to or more than } 5 \text { projects: } 1 \\
\text { Less than } 2 \text { projects: } 10\end{array}$ & $\begin{array}{c}\text { Number of } \\
\text { previous projects }\end{array}$ \\
\hline & & & $\begin{array}{l}\text { The number of joint- } \\
\text { venture/consortium } \\
\text { partners required }\end{array}$ & 0.862 & Project plan & $\begin{array}{l}\text { Equal to or less than } 1 \text { partner: } 1 \\
\text { More than } 8 \text { partners: } 10\end{array}$ & - \\
\hline & & & $\begin{array}{l}\text { The familiarity with the } \\
\text { general conditions of } \\
\text { the contract }\end{array}$ & 0.662 & $\begin{array}{l}\text { Internal } \\
\text { knowledge }\end{array}$ & $\begin{array}{l}\text { High level of familiarity: } 1 \\
\text { Low level of familiarity: } 10\end{array}$ & $\begin{array}{l}\text { Published by the } \\
\text { management } \\
\text { and planning } \\
\text { organization }\end{array}$ \\
\hline & & & $\begin{array}{l}\text { The previous } \\
\text { experience in project } \\
\text { type (contractor) }\end{array}$ & 0.887 & $\begin{array}{l}\text { Internal } \\
\text { documents }\end{array}$ & $\begin{array}{l}\text { Equal to or more than } 8 \text { projects: } 1 \\
\text { Less than } 3 \text { projects: } 10\end{array}$ & - \\
\hline \multirow{9}{*}{5} & \multirow{9}{*}{ 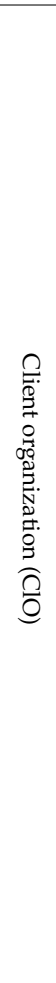 } & \multirow{9}{*}{0.22} & $\begin{array}{l}\text { The technical level of } \\
\text { the client staff }\end{array}$ & 0.65 & $\begin{array}{c}\text { Investigating } \\
\text { the client } \\
\text { organization }\end{array}$ & $\begin{array}{l}\text { High level of technical staff: } 1 \\
\text { Low level of technical staff: } 10\end{array}$ & - \\
\hline & & & $\begin{array}{l}\text { The Contractor } \\
\text { selection method }\end{array}$ & 0.700 & $\begin{array}{c}\text { Project } \\
\text { document }\end{array}$ & $\begin{array}{l}\text { Negotiation }=1 \\
\text { Limited bid }=5 \\
\text { Public bid }=10\end{array}$ & $\begin{array}{l}\text { Methods of } \\
\text { selecting a } \\
\text { contractor in } \\
\text { government } \\
\text { projects }\end{array}$ \\
\hline & & & $\begin{array}{l}\text { The credibility and rank } \\
\text { of the project designer } \\
\text { consultant }\end{array}$ & 0.867 & $\begin{array}{l}\text { The } \\
\text { corporations' } \\
\text { ranking bodies }\end{array}$ & $\begin{array}{l}\text { Degree } 1=1 \\
\text { Degree } 2=5 \\
\text { Degree } 3=10\end{array}$ & $\begin{array}{l}\text { Based on the list } \\
\text { of qualified } \\
\text { consultants } \\
\text { (national } \\
\text { program and } \\
\text { budget } \\
\text { organization) }\end{array}$ \\
\hline & & & $\begin{array}{c}\text { The level of confidence } \\
\text { in the financial strength } \\
\text { of the client }\end{array}$ & 0.885 & $\begin{array}{l}\text { Investigating } \\
\text { the client } \\
\text { organization }\end{array}$ & $\begin{array}{l}\text { High financial strength: } 1 \\
\text { Low financial strength: } 10\end{array}$ & - \\
\hline & & & $\begin{array}{l}\text { The typology of the } \\
\text { project system in the } \\
\text { client organization }\end{array}$ & 0.687 & $\begin{array}{c}\text { Investigating } \\
\text { the client } \\
\text { organization }\end{array}$ & $\begin{array}{c}\text { Project: } 1 \\
\text { Balanced matrix }=5 \\
\text { Functional }=10\end{array}$ & - \\
\hline & & & $\begin{array}{l}\text { The previous experience } \\
\text { of the consultant with } \\
\text { the client }\end{array}$ & 0.862 & $\begin{array}{l}\text { Investigating } \\
\text { the client } \\
\text { organization }\end{array}$ & $\begin{array}{l}\text { Equal to or more than } 5 \text { projects: } 1 \\
\text { Less than } 2 \text { projects: } 10\end{array}$ & $\begin{array}{l}\text { Number of } \\
\text { previous projects }\end{array}$ \\
\hline & & & $\begin{array}{l}\text { The financial instability } \\
\text { of the investors }\end{array}$ & 0.637 & $\begin{array}{l}\text { Investigating } \\
\text { the investors } \\
\text { organization }\end{array}$ & $\begin{array}{l}\text { High instability: } 1 \\
\text { Low instability: } 10\end{array}$ & - \\
\hline & & & $\begin{array}{c}\text { The bureaucratic level } \\
\text { of the client } \\
\text { organization }\end{array}$ & 0.737 & $\begin{array}{c}\text { Investigating } \\
\text { the client } \\
\text { organization }\end{array}$ & $\begin{array}{l}\text { Simple organizational pyramid: } 1 \\
\text { Complex organizational pyramid: } 10\end{array}$ & - \\
\hline & & & $\begin{array}{l}\text { The presence of the } \\
\text { construction manager } \\
\text { or program manager }\end{array}$ & 0.675 & $\begin{array}{l}\text { Project } \\
\text { document }\end{array}$ & $\begin{array}{l}\text { No CMA or PM: } 1 \\
\text { CMA or PM: } 10\end{array}$ & - \\
\hline
\end{tabular}


Table 6. Cont.

\begin{tabular}{|c|c|c|c|c|c|c|}
\hline $\begin{array}{c}\text { Main } \\
\text { Category }\end{array}$ & $\begin{array}{c}\text { Percentage } \\
\text { Weight }\left(p w_{i}\right)\end{array}$ & Factors & Weight $\left(w_{j}\right)$ & Reference & $\begin{array}{c}\text { Metrics Spectrum } \\
\text { (Low Complexity: 1; High Complexity: 10) }\end{array}$ & Description \\
\hline \multirow{19}{*}{ 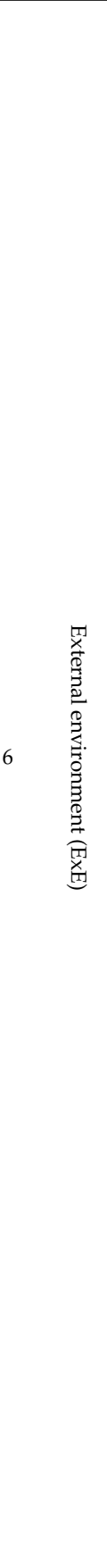 } & \multirow{19}{*}{0.08} & $\begin{array}{l}\text { The geophysical } \\
\text { conditions }\end{array}$ & 0.600 & Project design & $\begin{array}{l}\text { Conventional: } 1 \\
\text { Unconventional: } 0 \\
\end{array}$ & - \\
\hline & & $\begin{array}{l}\text { The number of required } \\
\text { approvals from } \\
\text { government entities }\end{array}$ & 0.575 & Project plan & $\begin{array}{l}\text { Equal to or less than } 15 \text { approvals: } 1 \\
\text { More than } 45 \text { partners: } 10\end{array}$ & - \\
\hline & & $\begin{array}{l}\text { The impact of national } \\
\text { politics on the project }\end{array}$ & 0.762 & $\begin{array}{l}\text { Investigating } \\
\text { the national } \\
\text { records }\end{array}$ & $\begin{array}{l}\text { Low level of impact: } 1 \\
\text { High level of impact: } 10\end{array}$ & $\begin{array}{l}\text { Changes in the } \\
\text { rules }\end{array}$ \\
\hline & & $\begin{array}{l}\text { The accessibility of the } \\
\text { material sources }\end{array}$ & 0.750 & $\begin{array}{l}\text { Investigating } \\
\text { the local } \\
\text { suppliers }\end{array}$ & $\begin{array}{l}\text { Low accessibility: } 10 \\
\text { High accessibility: } 1\end{array}$ & - \\
\hline & & $\begin{array}{l}\text { The amount of long } \\
\text { lead item (LLI) }\end{array}$ & 0.787 & $\begin{array}{l}\text { Project } \\
\text { document }\end{array}$ & $\begin{array}{l}\text { Low numbers of LLI: } 1 \\
\text { High numbers of LLI: } 10\end{array}$ & - \\
\hline & & $\begin{array}{l}\text { The environmental } \\
\text { impact assessment }\end{array}$ & 0.537 & Project plan & $\begin{array}{l}\text { Low level of impact: } 1 \\
\text { High level of impact: } 10\end{array}$ & $\begin{array}{l}\text { Positive or } \\
\text { negative, direct } \\
\text { or indirect, etc. }\end{array}$ \\
\hline & & $\begin{array}{l}\text { The social and cultural } \\
\text { environment of the } \\
\text { project }\end{array}$ & 0.800 & $\begin{array}{l}\text { Investigating } \\
\text { the local of the } \\
\text { project site }\end{array}$ & $\begin{array}{l}\text { Low level of diversity: } 1 \\
\text { High level of diversity: } 10\end{array}$ & $\begin{array}{l}\text { Variety of } \\
\text { different } \\
\text { languages }\end{array}$ \\
\hline & & $\begin{array}{l}\text { The accessibility of the } \\
\text { craftsmen or labors } \\
\text { locally }\end{array}$ & 0.750 & $\begin{array}{l}\text { Investigating } \\
\text { the local } \\
\text { suppliers }\end{array}$ & $\begin{array}{l}\text { Low accessibility: } 1 \\
\text { High accessibility: } 10\end{array}$ & - \\
\hline & & The weather severity & 0.487 & $\begin{array}{l}\text { Investigating } \\
\text { the local } \\
\text { weather } \\
\text { records }\end{array}$ & $\begin{array}{l}\text { Low level of severity: } 1 \\
\text { High level of severity: } 10\end{array}$ & - \\
\hline & & $\begin{array}{l}\text { The geological } \\
\text { conditions and } \\
\text { accessibility of the site }\end{array}$ & 0.600 & Project plan & $\begin{array}{l}\text { Conventional and accessible: } 1 \\
\text { Unconventional and out of access: } 10\end{array}$ & - \\
\hline & & $\begin{array}{l}\text { The level of government } \\
\text { binding standards }\end{array}$ & 0.500 & $\begin{array}{l}\text { Internal } \\
\text { knowledge }\end{array}$ & $\begin{array}{l}\text { Low number standards: } 1 \\
\text { High number standards: } 10\end{array}$ & - \\
\hline & & $\begin{array}{l}\text { Competition for the } \\
\text { project (market } \\
\text { attractiveness) }\end{array}$ & 0.787 & $\begin{array}{l}\text { Market } \\
\text { research }\end{array}$ & $\begin{array}{c}\text { Equal to or more than } 15 \text { competitors: } 1 \\
\text { less than } 4 \text { partners: } 10\end{array}$ & - \\
\hline & & $\begin{array}{l}\text { The records of local } \\
\text { protests in the region }\end{array}$ & 0.612 & $\begin{array}{l}\text { Investigating } \\
\text { the local } \\
\text { protest records }\end{array}$ & $\begin{array}{l}\text { Low level of previous records: } 1 \\
\text { High level of previous records: } 10\end{array}$ & $\begin{array}{l}\text { Protests that } \\
\text { disrupt the } \\
\text { project process }\end{array}$ \\
\hline & & $\begin{array}{l}\text { The local content } \\
\text { regulations }\end{array}$ & 0.512 & $\begin{array}{l}\text { Investigating } \\
\text { the local } \\
\text { regulations }\end{array}$ & $\begin{array}{l}\text { Low regulations: } 1 \\
\text { High regulations: } 10\end{array}$ & - \\
\hline & & Project location & 0.612 & Project plan & $\begin{array}{c}\text { Operational areas }=1 \\
\text { Rural areas }=3 \\
\text { Urban areas }=7 \\
\text { Urban area with restrictions }=10\end{array}$ & - \\
\hline & & $\begin{array}{c}\text { The degree of project } \\
\text { dependency on foreign } \\
\text { purchases }\end{array}$ & 0.812 & $\begin{array}{l}\text { Project plan } \\
\text { and BoM }\end{array}$ & $\begin{array}{l}\text { Equal to or less than USD } 100 \text { million: } 1 \\
\text { More than USD } 1.2 \text { billion: } 10\end{array}$ & $\begin{array}{c}\text { Purchase of } \\
\text { equipment or } \\
\text { services abroad }\end{array}$ \\
\hline & & $\begin{array}{l}\text { The level of supervision } \\
\text { of the local entities }\end{array}$ & 0.525 & $\begin{array}{l}\text { Investigating } \\
\text { the local } \\
\text { entities }\end{array}$ & $\begin{array}{l}\text { Low supervision: } 1 \\
\text { High supervision: } 10\end{array}$ & $\begin{array}{c}\text { General } \\
\text { supervision or } \\
\text { detail control }\end{array}$ \\
\hline & & $\begin{array}{l}\text { The geographical } \\
\text { distribution of the } \\
\text { project's site }\end{array}$ & 0.662 & $\begin{array}{l}\text { Project basic } \\
\text { design }\end{array}$ & $\begin{array}{l}\text { Equal to or less than } 1 \text { legal area (province): } 1 \\
\text { More than } 5 \text { legal areas (province): } 10\end{array}$ & - \\
\hline & & $\begin{array}{l}\text { The probability of } \\
\text { alteration in project } \\
\text { rules and regulations }\end{array}$ & 0.762 & $\begin{array}{l}\text { Investigating } \\
\text { the local } \\
\text { entities }\end{array}$ & $\begin{array}{l}\text { Low probability: } 1 \\
\text { High probability: } 10\end{array}$ & - \\
\hline
\end{tabular}

Consequently, using Equation (1), a model was developed in which, based on it, the complexity of a given project can be estimated. The input of this model is characteristics of the project, and the output will be the project complexity index (PCI), which is a real number between 1 for the lowest complexity and 10 for the highest complexity. As pointed out earlier, a vast number of criteria in different levels may be involved in the contractor's decision about a prospective tender such as an international and/or national economic situation and considerations of the intended sector in the industry. The focus of this study is on the features of a project, and the other factors are considered fixed variables. However, in the next step the connection between the PCI spectrum and the size of the project mark-up is investigated. 


\subsection{Mark-Ups of Contractor's Proposal}

The legal procedure for contracting through the tender method concludes through an objective process called offer (from the client as offeror) and acceptance (with the contractor as offeree). The proposal of the contractor as the acceptance side of the contract includes the two significant aspects of time and cost, which must be exactly determined to cover the contractual risk of the contractor appropriately and at the same time support the competitiveness in comparison with the other bids. Therefore, to win the tender, the determination of the cost and time mark-ups in a systematic way is crucial for contractors. The contractors of the construction industry traditionally propose their bids, taking into account many factors and parameters that were summarized in the project complexity index in this study. It is worth mentioning that in addition to the PCI, the contractor may consider the other parameters from outside the project level, such as political or other related considerations, to prepare a bid. For instance, it is not uncommon for a contractor to provide a proposal that is underestimated and under the price of the market for many reasons, such as continuing to be present in a growing sector of the economy, improving relationships with a famous client, and/or preserving the expert personnel of the organization. It is obvious that these subjective and case-based criteria were not included in the current research, and therefore, they are considered constant factors in this investigation. However, to point to the second question of this study, utilizing a regression method based on historical data from 139 projects implemented by 8 well-known Iranian contractors in the last 12 years, the proposed bids in terms of time and cost were analyzed. In accordance with available data from these projects, the PCI was determined for each project, and based on the mapping with times and costs of the selected projects, the relations between the PCI and cost-time mark-ups were determined. Finally, the functions that define the relation between the $\mathrm{PCI}$ and $\mathrm{CMU}$ or TMU were determined through curve fitting with the winners' bids as the following form: $\mathrm{CMU}=\mathrm{F}(\mathrm{PCI})$; $\mathrm{TMU}=\mathrm{F}(\mathrm{PCI})$.

Since the obtained functions were not accurate enough at the first overall curve fitting (Figure 4), they were subdivided into quadratic exponential subfunctions until the accuracy of each of them reached more than $80 \%$. These functions were formed as eight models for CMU (Table 7) and seven models for TMU (Table 8). As mentioned earlier, data from 111 projects were utilized to develop the CMU and TMU generator functions based on the PCI. Analysis of the above-mentioned data shows that if the PCI becomes more that 8.38 for CMU and more than 8.85 for TMU, there are no supportive data to turn out the mark-ups. This fact may be due to two reasons:

1. Substantially, there are no projects in this section of the industry with this level of complexity; or

2. The contractors decide not to participate in the tender with high complexity (no-bid decision).
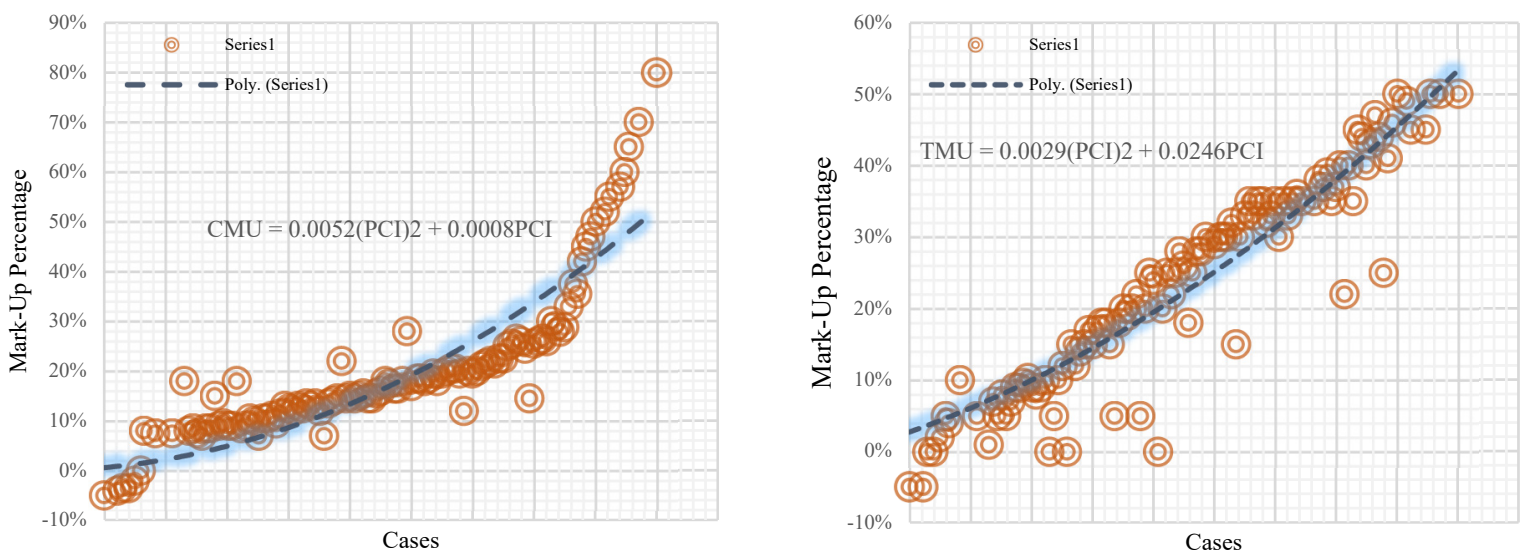

Figure 4. Cost (left) and time (right) mark-up data used for curve fitting and for developing the primary model. 
Table 7. Relation between the PCI and CMU based on data from 111 projects.

\begin{tabular}{|c|c|c|c|c|c|c|c|}
\hline \multirow{2}{*}{ Ranges } & \multicolumn{2}{|c|}{ PCI } & \multirow{2}{*}{ First Decision } & \multirow{2}{*}{ Time Mark-Up (CMU) Model } & \multirow{2}{*}{ Accuracy } & \multicolumn{2}{|c|}{ CMU } \\
\hline & Lower Limit & Upper Limit & & & & Lower Limit & Upper Limit \\
\hline $\mathrm{RC} 1$ & 1 & 1.6 & Bid & CMU1 $=0.1391(\mathrm{PCI}) 2-0.2857(\mathrm{PCI})+0.0981$ & $86.3 \%$ & -0.0485 & -0.0029 \\
\hline $\mathrm{RC} 2$ & 1.61 & 3.30 & Bid & $\mathrm{CMU} 2=-0.0047(\mathrm{PCI}) 2+0.04(\mathrm{PCI})+0.0261$ & $87.2 \%$ & 0.0783 & 0.1069 \\
\hline RC3 & 3.31 & 4.65 & Bid & CMU3 $=-0.0515(\mathrm{PCI}) 2+0.4352(\mathrm{PCI})-0.796$ & $87.7 \%$ & 0.0802 & 0.1141 \\
\hline $\mathrm{RC} 4$ & 4.66 & 5.43 & Bid & $\mathrm{CMU} 4=-0.0378(\mathrm{PCI}) 2+0.3669(\mathrm{PCI})-0.7334$ & $86.6 \%$ & 0.1555 & 0.1443 \\
\hline RC5 & 5.44 & 6.28 & Bid & CMU5 $=-0.1756(\mathrm{PCI}) 2+2.0976(\mathrm{PCI})-6.0668$ & $91.7 \%$ & 0.1475 & 0.1807 \\
\hline RC6 & 6.29 & 7.06 & Bid & CMU6 $=0.0411(\mathrm{PCI}) 2-0.5606(\mathrm{PCI})+2.0985$ & $87.8 \%$ & 0.1984 & 0.1892 \\
\hline $\mathrm{RC7}$ & 7.07 & 8.37 & Bid & $\mathrm{CMU} 7=0.0262(\mathrm{PCI}) 2-0.3548(\mathrm{PCI})+1.4146$ & $85.4 \%$ & 0.2157 & 0.2804 \\
\hline $\mathrm{RC} 8$ & 8.38 & 10 & No Bid & CMU8 $=0.0083(\mathrm{PCI}) 2+0.1553(\mathrm{PCI})-1.5929$ & $85.5 \%$ & 5.5371 & 8.2601 \\
\hline
\end{tabular}

Table 8. Relation between the PCI and TMU based on data from 111 projects.

\begin{tabular}{|c|c|c|c|c|c|c|c|}
\hline \multirow{2}{*}{ Ranges } & \multicolumn{2}{|c|}{ PCI } & \multirow{2}{*}{ First Decision } & \multirow{2}{*}{ Time Mark-Up (TMU) Model } & \multirow{2}{*}{ Accuracy } & \multicolumn{2}{|c|}{ TMU } \\
\hline & Lower Limit & Upper Limit & & & & Lower Limit & Upper Limit \\
\hline RT1 & 1 & 2.11 & Bid & TMU1 $=-0.1141(\mathrm{PCI}) 2+0.4805(\mathrm{PCI})-0.4367$ & $82.1 \%$ & -0.0703 & 0.0691 \\
\hline RT2 & 2.12 & 3.37 & Bid & TMU2 $=-0.1912(\mathrm{PCI}) 2+1.0928(\mathrm{PCI})-1.4692$ & $85.6 \%$ & -0.0117 & 0.0420 \\
\hline RT3 & 3.37 & 4.44 & Bid & TMU3 $=-0.2121(\mathrm{PCI}) 2+1.7347(\mathrm{PCI})-3.3881$ & $86.4 \%$ & 0.0490 & 0.1327 \\
\hline RT4 & 4.45 & 5.78 & Bid & TMU4 $=0.109(\mathrm{PCI}) 2-1.0447(\mathrm{PCI})+2.6831$ & $83.3 \%$ & 0.1926 & 0.2862 \\
\hline RT5 & 5.79 & 7.83 & Bid & TMU5 $=-0.003(\mathrm{PCI}) 2+0.0874(\mathrm{PCI})-0.1286$ & $85.3 \%$ & 0.2768 & 0.3718 \\
\hline RT6 & 7.84 & 8.84 & Bid & TMU6 $=-0.5722(\mathrm{PCI}) 2+9.7284(\mathrm{PCI})-40.822$ & $83.5 \%$ & 0.2780 & 0.4621 \\
\hline RT7 & 8.85 & 10 & No Bid & TMU7 $=0.0429(\mathrm{PCI}) 2-0.786(\mathrm{PCI})+4.0699$ & $80.4 \%$ & 0.4738 & 0.4999 \\
\hline
\end{tabular}

Both of these two reasons lead the model to define the no-bid area for the abovementioned project complexity factors (Figure 5). Note that the no-bid area in Figure 5 means that in these levels of complexity, considering all affecting factors, in which majority of them are related to project-inherent characteristics and the contractor appropriateness for the project's overall surrounding system and its client organization, it is not logical for the contractor to move forward. The other remarkable point here is the dumping price of the contractors in comparison with the client estimations in the case of low complexity projects. Clearly, based on available data, this phenomenon occurs in the complexity indices at less than 1.6 and 2.12 for the CMU and TMU, respectively. It is worth mentioning that the CMU and TMU are not following the same trends for growth versus the PCI (Figure 6).

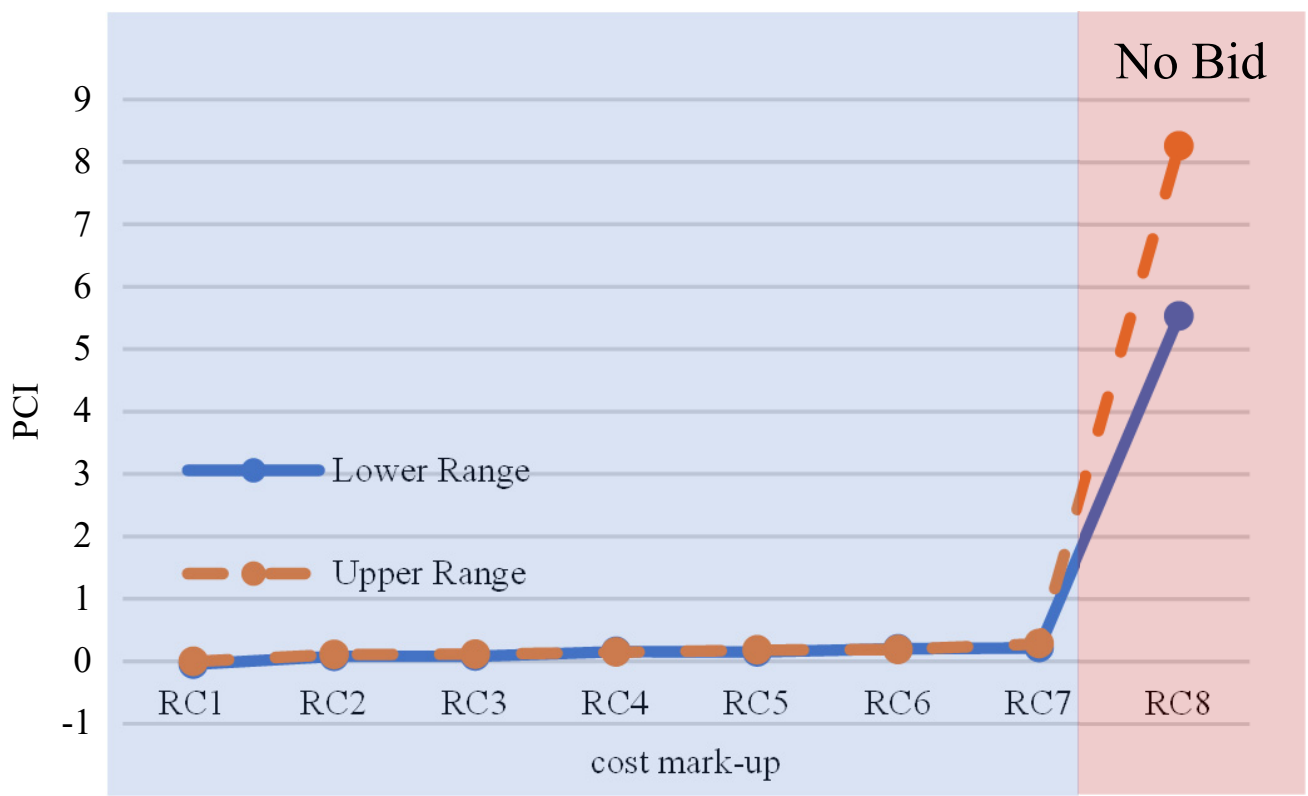

Figure 5. The no-bid area based on the analyzed data. 

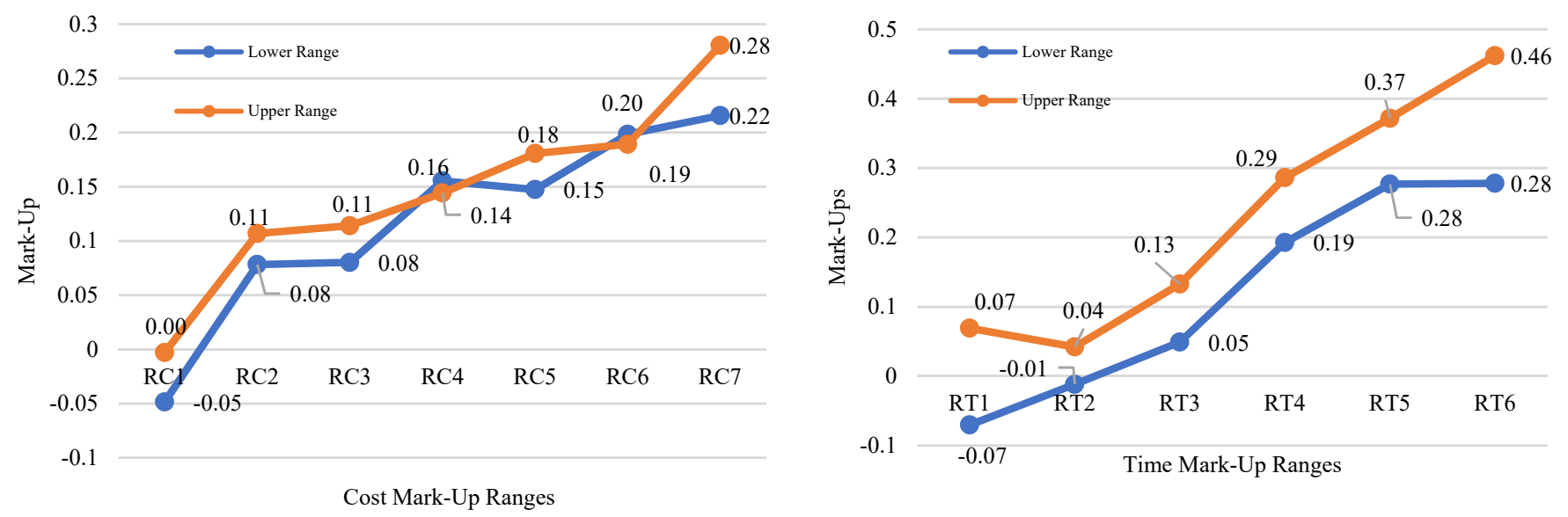

Figure 6. Trend of changing the upper and lower limits of the CMU (left) and TMU (right) without the no-bid area.

\subsection{Model Validation and Research Limitations}

As mentioned earlier, data from 28 projects were considered to assess the developed model. These projects were selected in such a way that there are all kinds of projects in the composition of the test data. For this purpose, the PCI of each project was estimated using the available data, and subsequently based on this index and the developed models, the CMU and TMU were calculated for each project. Eventually, the calculated markups as outcome of the proposed model were compared with the actual amounts of bid winners (Table 9). Results reveal that the complexity-based model to support the bid/nobid decision and afterward to figure out the mark-ups for the time and cost of project, in the context of the downstream sector of the petroleum industry of Iran, can lead to reliable outputs. The average accuracy calculated for the time and cost mark-up is $74.670 \%$ and $75.364 \%$, respectively; and the error rate for these two indices is $11.096 \%$ and $-9.239 \%$, respectively. The above results, which are expressed as percentage of accuracy and error, can be interpreted as follows:

1. Accuracy in both aspects of time and cost is close to $75 \%$. Based on this fact, it can be inferred that the process of model development based on the discovery of the relation between project complexity and bid mark-ups makes sense overall. Otherwise, the calculated accuracy of the two separate datasets would have to be notably separated from each other.

2. The model results are higher or lower than the actual data, and this can be seen in the positive and negative sign of the errors. The mean of the errors, regardless of their signs, is about $10 \%$ at both the time and cost mark-ups, meaning that the data collected for model development in both respects behaved similarly, and therefore, the results are reliable at around $90 \%$.

3. It can be inferred from the rate of accuracy against the PCI that this trend almost follows a normal distribution (Figure 7). This fact means that the reliability of the developed model is lower in low and high complexities and higher in complexities diffused around the mean. In fact, in the case of projects with high or low complexity, the contractors' bids do not necessarily fully follow the logical pattern of the relationship between coefficients' determination and subjective understanding of the complexity of the project. 

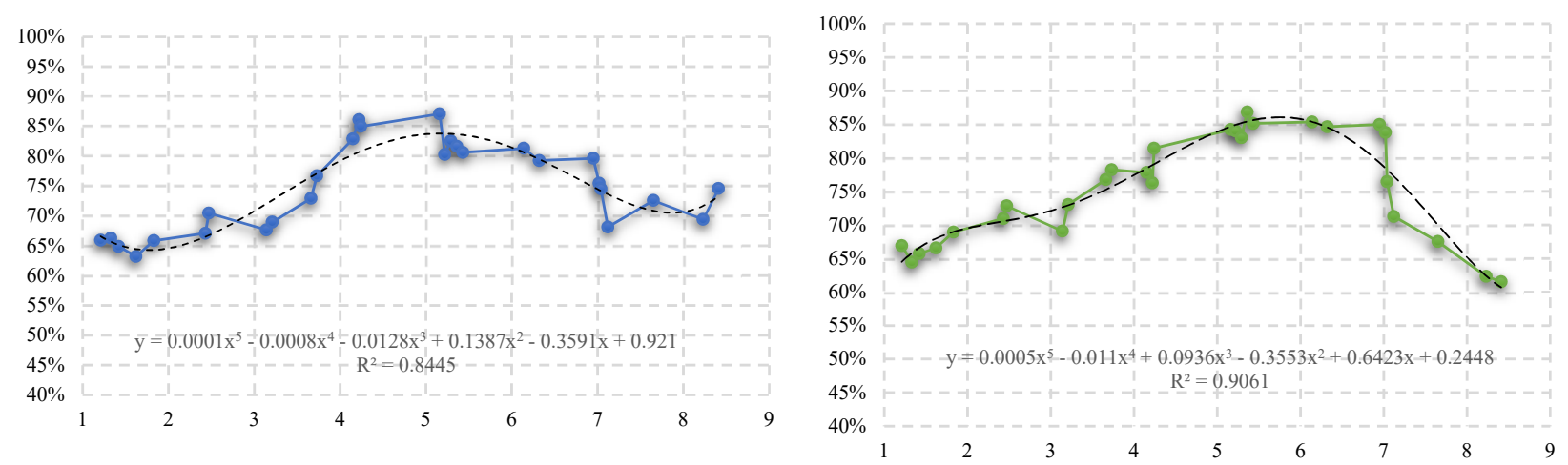

Figure 7. Correlation between the PCI and the percentage of the results' accuracy time mark-up (left) and cost mark-up (right).

Table 9. Accuracy of the outputs of the proposed model versus the actual data.

\begin{tabular}{|c|c|c|c|c|c|c|c|c|c|}
\hline \multirow{2}{*}{ Test Data } & \multirow{2}{*}{ PCI } & \multicolumn{2}{|c|}{ Actual } & \multicolumn{2}{|c|}{ Model } & \multicolumn{2}{|c|}{ Accuracy } & \multicolumn{2}{|c|}{ Error } \\
\hline & & TMU & CMU & TMU & CMU & $\mathrm{T}$ & $\mathrm{C}$ & $\mathbf{T}$ & $\mathrm{C}$ \\
\hline Project 01 & 2.43 & $4.31 \%$ & $6.78 \%$ & $5.73 \%$ & $9.56 \%$ & $67.076 \%$ & $70.957 \%$ & $32.924 \%$ & $29.043 \%$ \\
\hline Project 02 & 7.12 & $50.14 \%$ & $30.39 \%$ & $34.16 \%$ & $21.66 \%$ & $68.129 \%$ & $71.273 \%$ & $-31.871 \%$ & $-28.727 \%$ \\
\hline Project 03 & 1.21 & $-3.39 \%$ & $-2.94 \%$ & $-2.24 \%$ & $-4.39 \%$ & $65.929 \%$ & $66.909 \%$ & $34.071 \%$ & $-33.091 \%$ \\
\hline Project 04 & 3.14 & $5.82 \%$ & $15.25 \%$ & $7.70 \%$ & $10.54 \%$ & $67.628 \%$ & $69.088 \%$ & $32.372 \%$ & $-30.912 \%$ \\
\hline Project 05 & 1.62 & $3.09 \%$ & $5.23 \%$ & $4.23 \%$ & $7.86 \%$ & $63.203 \%$ & $66.564 \%$ & $36.797 \%$ & $33.436 \%$ \\
\hline Project 06 & 4.22 & $18.02 \%$ & $16.18 \%$ & $15.52 \%$ & $12.34 \%$ & $86.109 \%$ & $76.273 \%$ & $-13.891 \%$ & $-23.727 \%$ \\
\hline Project 07 & 1.33 & $-0.08 \%$ & $-2.31 \%$ & $0.05 \%$ & $-3.58 \%$ & $66.250 \%$ & $64.471 \%$ & $33.750 \%$ & $-35.529 \%$ \\
\hline Project 08 & 3.73 & $10.08 \%$ & $14.16 \%$ & $13.14 \%$ & $11.08 \%$ & $76.706 \%$ & $78.234 \%$ & $23.294 \%$ & $-21.766 \%$ \\
\hline Project 09 & 7.02 & $25.43 \%$ & $22.50 \%$ & $33.71 \%$ & $18.85 \%$ & $75.435 \%$ & $83.782 \%$ & $24.565 \%$ & $-16.218 \%$ \\
\hline Project 10 & 2.47 & $9.02 \%$ & $7.01 \%$ & $6.35 \%$ & $9.62 \%$ & $70.452 \%$ & $72.846 \%$ & $-29.548 \%$ & $27.154 \%$ \\
\hline Project 11 & 5.16 & $16.95 \%$ & $18.21 \%$ & $19.46 \%$ & $15.34 \%$ & $87.083 \%$ & $84.217 \%$ & $12.917 \%$ & $-15.783 \%$ \\
\hline Project 12 & 5.22 & $16.04 \%$ & $13.76 \%$ & $19.98 \%$ & $15.18 \%$ & $80.264 \%$ & $84.000 \%$ & $19.736 \%$ & $16.000 \%$ \\
\hline Project 13 & 3.21 & $5.23 \%$ & $14.52 \%$ & $6.85 \%$ & $10.61 \%$ & $68.948 \%$ & $73.051 \%$ & $31.052 \%$ & $-26.949 \%$ \\
\hline Project 14 & 5.29 & $17.08 \%$ & $18.03 \%$ & $20.69 \%$ & $14.97 \%$ & $82.552 \%$ & $83.028 \%$ & $17.448 \%$ & $-16.972 \%$ \\
\hline Project 15 & 7.04 & $45.36 \%$ & $24.71 \%$ & $33.80 \%$ & $18.89 \%$ & $74.515 \%$ & $76.446 \%$ & $-25.485 \%$ & $-23.554 \%$ \\
\hline Project 16 & 6.14 & $23.98 \%$ & $22.54 \%$ & $29.49 \%$ & $19.24 \%$ & $81.304 \%$ & $85.363 \%$ & $18.696 \%$ & $-14.637 \%$ \\
\hline Project 17 & 4.15 & $13.05 \%$ & $9.58 \%$ & $15.80 \%$ & $12.31 \%$ & $82.897 \%$ & $77.810 \%$ & $17.103 \%$ & $22.190 \%$ \\
\hline Project 18 & 6.32 & $24.09 \%$ & $23.29 \%$ & $30.39 \%$ & $19.71 \%$ & $79.259 \%$ & $84.645 \%$ & $20.741 \%$ & $-15.355 \%$ \\
\hline Project 19 & 5.43 & $18.08 \%$ & $12.29 \%$ & $22.42 \%$ & $14.43 \%$ & $80.631 \%$ & $85.142 \%$ & $19.369 \%$ & $14.858 \%$ \\
\hline Project 20 & 8.23 & $70.03 \%$ & $43.18 \%$ & $48.60 \%$ & $26.92 \%$ & $69.398 \%$ & $62.343 \%$ & $-30.602 \%$ & $-37.657 \%$ \\
\hline Project 21 & 5.36 & $17.55 \%$ & $16.95 \%$ & $21.50 \%$ & $14.72 \%$ & $81.616 \%$ & $86.849 \%$ & $18.384 \%$ & $-13.151 \%$ \\
\hline Project 22 & 6.95 & $26.59 \%$ & $22.07 \%$ & $33.39 \%$ & $18.76 \%$ & $79.629 \%$ & $84.984 \%$ & $20.371 \%$ & $-15.016 \%$ \\
\hline Project 23 & 8.41 & $70.17 \%$ & $46.88 \%$ & $52.32 \%$ & $28.38 \%$ & $74.561 \%$ & $61.537 \%$ & $-25.439 \%$ & $-38.463 \%$ \\
\hline Project 24 & 1.42 & $1.15 \%$ & $-1.78 \%$ & $1.55 \%$ & $-2.71 \%$ & $64.869 \%$ & $65.732 \%$ & $35.131 \%$ & $-34.268 \%$ \\
\hline Project 25 & 1.83 & $4.51 \%$ & $5.76 \%$ & $6.05 \%$ & $8.36 \%$ & $65.831 \%$ & $68.932 \%$ & $34.169 \%$ & $31.068 \%$ \\
\hline Project 26 & 3.66 & $9.42 \%$ & $8.21 \%$ & $11.97 \%$ & $10.70 \%$ & $72.929 \%$ & $76.757 \%$ & $27.071 \%$ & $23.243 \%$ \\
\hline Project 27 & 7.65 & $50.21 \%$ & $34.61 \%$ & $36.44 \%$ & $23.37 \%$ & $72.575 \%$ & $67.523 \%$ & $-27.425 \%$ & $-32.477 \%$ \\
\hline Project 28 & 4.24 & $18.12 \%$ & $10.05 \%$ & $15.40 \%$ & $12.34 \%$ & $84.977 \%$ & $81.445 \%$ & $-15.023 \%$ & $18.555 \%$ \\
\hline \multicolumn{6}{|c|}{ Average } & $74.670 \%$ & $75.364 \%$ & $11.096 \%$ & $-9.239 \%$ \\
\hline
\end{tabular}


Although the findings confirm that the developed model based on the complexity factors and the model definitely has a strong capacity to expand to other sectors in the construction industry in different countries, the following should be kept in mind as model limitations, which may affect the final results:

1. The model was established based on gathered data from: (a) projects in the downstream sector of the petroleum industry and (b) professionals in construction projects in Iran. Therefore, any effort to adapt the model to other sectors may need to re-review the complexity factors and modify the mark-up scales, and may necessitate considering specific parameters of the selected sector to develop a customized a model.

2. Another limiting factor in the validation process is that decision making by the contractor in the tender process is a complicated multilateral problem that needs to reckon several attributes, which are held by those in the organization as vital internal or maybe even tacit knowledge. Therefore, it is not surprising that a wide range of quantitative, qualitative, and mixed approaches with different methodologies for modeling, inference, or reasoning can be observed in previous studies. Accordingly, comparing results with previous research is actually impossible, because any attempt in this regard will lead to a comparison of apples and oranges.

3. Another limitation of the study is the number of projects (139) that were applied for both model training in the regression analysis and for testing of the developed model. Consequently, it is obvious that the resulting mathematical model was vigorously curbed by the volume of the database, which can be improved in the next investigations by expanding the input information for model training.

\section{Discussion}

\subsection{A Bid/Mark-Up Decision Support Model and Firm Strategy under Complexity}

The current study aims to examine one of the key decisions in the preproject phase, tendering strategy, by exploring the relationship between the inherent project characteristics and a key feature of a bid from the perspective of the contractor. Although there are dozens of research studies in the literature that have investigated this key decision of the contractor $[8,10,35,36]$, the two-folded gap including modeling the complexity factors of the project and considering the schedule parameter of the project is obvious in previous studies. Accordingly, the current study models the complexity of a project as a foundation for the development of the contractor's bid strategy. Therefore, in the current study a model was developed to support key decisions for the bid proposal preparation phase (Figure 8).

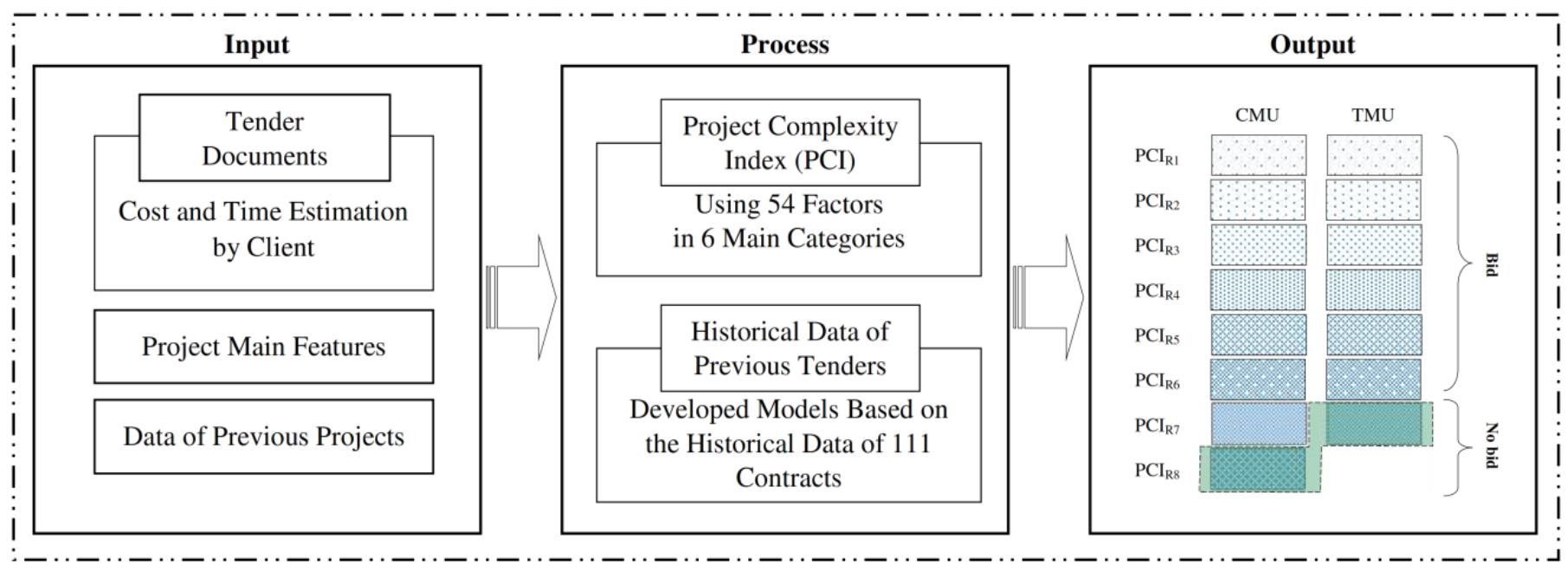

Figure 8. Schematic view of the proposed model. 
The proposed model supports the decision to bid or not bid and the determination of appropriate mark-ups regarding project-specific features using the estimation of project complexity. The model was formed using historical data from 139 previous successful projects, utilizing regression analysis to develop the mathematical patterns and to test the model. Results show that there are meaningful relationships between project-complexitymeasuring factors and the tender strategy with a reliability of around $90 \%$. The input of the introduced model includes tender documents announced by the client of the project, which normally encompass the estimations on the client side. Additionally, the other features of the project and data related to previous projects are considered as the input of the model. The process of the provided model is to calculate the project complexity index (PCI) based on the historical data using 54 factors, which are organized into 6 main categories. The output of the model is to present cost and time mark-ups as the coefficients that the contractor will propose in the bid proposal. As shown in the output in Figure 8 , where the complexity index rises above the defined ranges, it is recommended to refrain from offering a bid.

\subsection{A Bid/Mark-Up Decision Support Model and Open Innovation Dynamics}

From another perspective, it is important to analyze the developed decision support model from the viewpoint of complexity science and open innovation. This area of knowledge has deep application and novel approaches for problem solving in a wide range of domains-for instance, technology transfer performance [92]; adoption of new technologies, such as blockchain, big data, artificial intelligence, 3D printing, and virtual and augmented reality [93,94]; dynamics of business models [95-97]; quality analysis of complex products [98,99]; performance of corporate entrepreneurship [100-102]; design rules and modular architectures [103]; digital transformation in the banking sector [104]; and R\&D innovation $[105,106]$.

It is notable that results reveal that the complexity index of a project has a direct correlation with the bid mark-ups of time and cost. This can be interpreted as a fact that when a project becomes more complex, the overall risk of a project proceeds to go higher, and the contractors, to cover uncertainties, propose greater profit/schedule coefficients. The other fact here is that in the case of projects with the highest and lowest complexities, the accuracy of the project mark-up is lower, and medium ranges of the PCI the TMU and CMU are more accurate. This interesting fact may happen due to the higher unfamiliarity of contractors with out-of-normal ranges or unusual projects. However, contractors should be aware that the probability of error in the lowest and the highest ranges of the PCI is larger, and they should scrutinize more the process of bid development in these cases. Tendering is a mandatory step to award projects in the public and government sector of Iran following a rigid predefined process and procedures, which must be fulfilled within a bound deadline. Additionally, contractors must go through the prequalification process and afterwards have to submit a bid bond to guarantee the proposed cost and time. The above-mentioned hard tendering process on the one hand and the probability of occurrence of tremendous mistakes in the bid proposal on the other hand make decision making and bid coefficients ${ }^{\prime}$ determination doubly important. It is not unusual that an underestimated bid proposal leads to winning in a tender, a proposal that is not practical in the implementation phase, or an overestimated bid causes the long relations with a prospective client to deteriorate. Therefore, holding forth the benefit margin of the company and at the same time keeping mutual relations with the client must be considered in the bid submission. Accordingly, the proposed model can be effectively used to determine the level of complicacy of a project and can be applied as a quantitative method to support a critical decision about a risk assessment of a venture. Furthermore, to estimate the profit margin in the form of cost and time mark-ups, the provided model can be helpful. Note that this model is capable of approximating the complexity of a project and, thereafter, of proposing the mark-ups based on a series of developed equations empowered by historical data. The decision support model described above can be represented and concluded as a decision tree, as shown in 
Figure 9. It is worth mentioning that the model can be adopted by all contractors in the downstream sector of the petroleum industry in other countries and nations, the presented methodology can be applied to all other projects, and the illustrated results have strong compatibility with other types of projects in the construction industry and also in other regions by adjusting/adding the specific complexity factors.

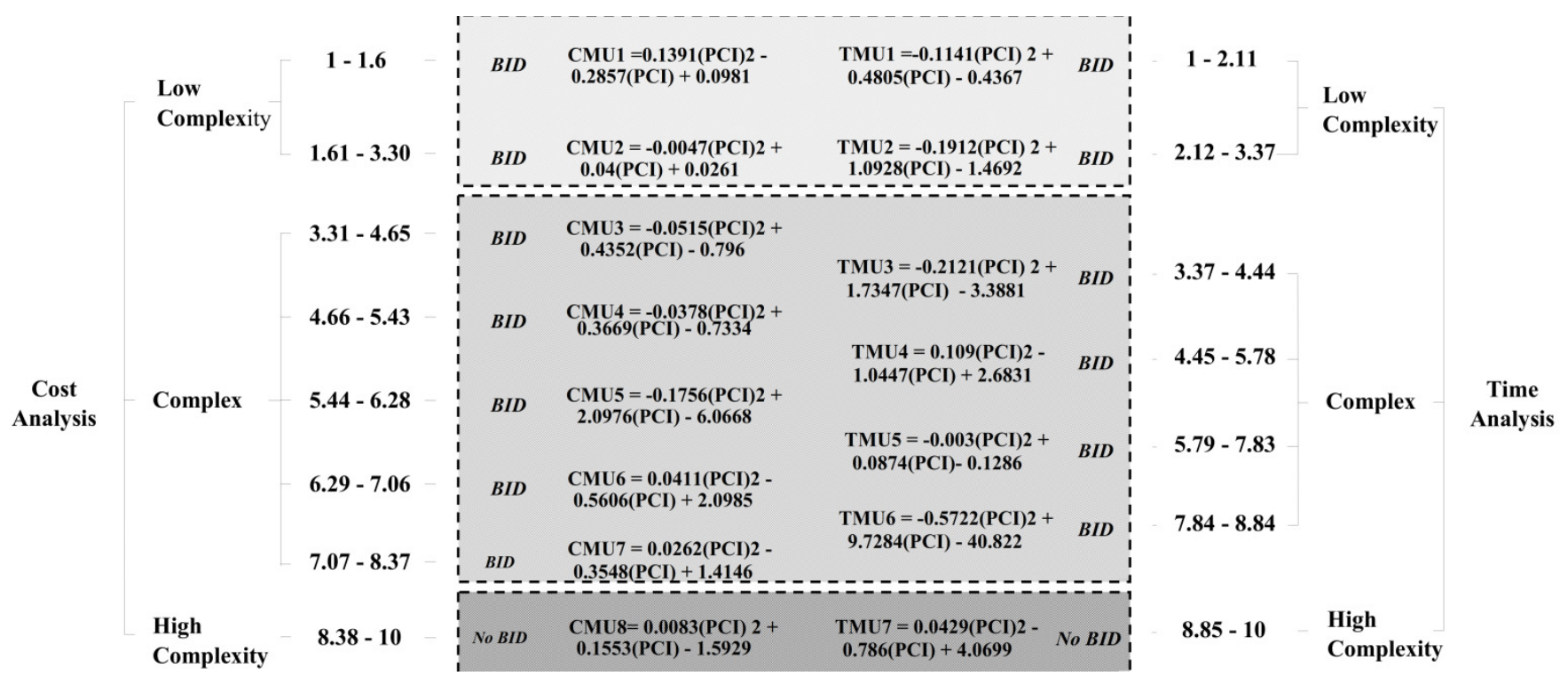

Figure 9. The presented model in the form of a decision tree of bid/no-bid and mark-up sizes.

\section{Implication and Future Research Topic}

In the current study, an investigation was conducted to address the problem of a bid or no-bid decision by the contractor side of a probabilistic contract in the context of the downstream sector of the petroleum industry, and eventually a two-stage model was proposed as the finding of the research. Using the proposed model and based on 54 effective factors, the complexity of a prospective project will be indexed. This parameter as the project complexity factor (PCI) can be used to predict the cost and time mark-ups, which are recognized as the most critical coefficient in the contractor technical-commercial bid.

Tenders in the downstream sector of the petroleum industry in Iran and all over the world are very tight, time-driven, and costly processes, and this competitive procedure can be considered one of the crucial business processes of contractorship; for that reason, the tender department is one of the main and constant sections in all contractors' organizational chart all over this industry. However, nowadays neither price nor time is the sole criterion for selecting a contractor by a client; and normally, a vast number of criteria are employed for contractor selection, from early screenings to rigid qualifications, but the cost effectiveness of the contractor's bid is still a critical factor in tenders' process in the construction industry. The price offer of the contractor must take into account factors, many of which are difficult to express in a quantitative manner. A vast part of these factors is considered by the contractor in a subjective judgement process, and it is even not uncommon for some of them to be overlooked in complicated, time-consuming, and costly efforts to participate in construction tenders. It is common in the society of Iranian contractors to apply the terms plus (when the contractor's offer is greater than the client's released estimation) and minus (when the contractor's offer is less than the client's released estimation) to explain the appropriateness of a mark-up in competitive tenders in the construction industry. For example, a bid with $5 \%$ plus or $8 \%$ minus means a proposed coefficient of 0.95 or 1.08 to the customer estimate. It is obvious that the determination of such coefficient can be vital for a contractor. Developing a tender strategy can be deemed one of the core organizational assets of prosperous contractors that probably will never be revealed, because the main 
stream of business of a construction corporation is vigorously tied up to this knowledge. Thus, it is vital for new companies entering the market to have competent knowledge about the principles of tendering as a core organizational competency.

In practice, the contractor considers a certain price range and will only consider bids in that range and, using previous experience and a subjective sense of the executive and commercial environment, prepares a reasonable price offer. The above process is not systematic, does not include all parameters, and can lead to tender failure or profit loss, especially for those who are recognized as newly established businesses in the field of tenders. Therefore, it is highly recommended that contractors, using historical data and available information about the defined project, evaluate the project complexity level and, on the basis of this assessment, determine the mark-up sizes. It is obvious that there are other factors that may need to be taken into account by the contractor in the tender strategy development phase, such as maintaining relations with a client or remaining in a competitive sector of a market. Additionally, according to major strategy shifts in the petroleum industry, to diversify energy baskets in recent years, including solar, hydropower, wind, and the other renewable source of energies, it seems inevitable that the downstream sector, including oil and gas refineries and petrochemicals, take into account broader factors to expand their business models. Therefore, it will be worthwhile to have future studies on the following: (1) bid mark-up sizes in other sectors of the construction industry and (2) risk analysis of bid proposals from the standpoints of the contractor and the client.

Author Contributions: Conceptualization, A.F.; methodology, A.F., M.R. and S.P.; validation, A.F., M.R. and N.A.E.; investigation, A.F. and N.A.E.; resources, S.M.; writing-original draft preparation, A.F. and N.A.E.; writing-review and editing, A.F., N.A.E. and S.P.; supervision, M.R.; project administration, M.R. All authors have read and agreed to the published version of the manuscript.

Funding: This research received no internal or external funding from any commercial or noncommercial source.

Institutional Review Board Statement: Not applicable.

Informed Consent Statement: Not applicable.

Data Availability Statement: All data have been presented in the text.

Conflicts of Interest: The authors declare no conflict of interest.

\section{References}

1. Shash, A.A. Factors considered in tendering decisions by top UK contractors. Constr. Manag. Econ. 1993, 11, 111-118. [CrossRef]

2. Soltaninejad, M.; Faraji, A.; Noorzai, E. Recognizing the effective factors in managing fire incidents to reduce the collateral damages and casualties. Facilities 2021. ahead-of-print. [CrossRef]

3. Faraji, A.; Rashidi, M.; Tezangi, M.R.; Perera, S. Multihybrid Dispute Resolution Framework for Projects of Downstream Sector of Petroleum Industry. J. Leg. Aff. Disput. Resolut. Eng. Constr. 2021, 13, 4521026. [CrossRef]

4. Golabchi, M.; Faraji, A. Project Strategic Management; Press University of Tehran: Tehran, Iran, 2010.

5. Tavakoli, A.; Utomo, J. Bid markup assistant: An expert system. Cost Eng. 1989, 31, 28.

6. Carr, R.I.; Sandahl, J.W. Bidding strategy using multiple regression. J. Constr. Div. 1978, 104, 15-26. [CrossRef]

7. Ahmad, I.; Minkarah, I. An expert system for selecting bid markups. In Proceedings of the Computing in Civil Engineering: Microcomputers to Supercomputers; ASCE: Reston, VA, USA, 1988; pp. 229-238.

8. Kalan, D.; Ozbek, M.E. Development of a Construction Project Bidding Decision-Making Tool. Pract. Period. Struct. Des. Constr. 2020, 25, 04019032. [CrossRef]

9. Kumar, J.K.; Raj, V. A Study on Key Factors Influencing Bid Decision Model for Construction Projects. In IOP Conference Series: Materials Science and Engineering; IOP Publishing: Bristol, UK, 2019; Volume 574, p. 12004.

10. Chileshe, N.; Kavishe, N.; Edwards, D.J. Critical factors influencing the bid or no-bid decision of the indigenous small building contractors in Tanzania. Constr. Innov. 2020, 21, 182-202. [CrossRef]

11. Egemen, M.; Mohamed, A. SCBMD: A knowledge-based system software for strategically correct bid/no bid and mark-up size decisions. Autom. Constr. 2008, 17, 864-872. [CrossRef]

12. Drew, D.; Skitmore, M.; Lo, H.P. The effect of client and type and size of construction work on a contractor's bidding strategy. Build. Environ. 2001, 36, 393-406. [CrossRef]

13. El-Mashaleh, M.S.; Al-Jundi, A.; Mattar, S.; Abu Ali, R.; Al-Hammad, J. Understanding key bidding factors considered by top Jordanian contractors. Jordan J. Civ. Eng. 2014, 159, 1-10. 
14. Faraji, A.; Rashidi, M.; Sorooshnia, E. An Integrated Organizational System for Project Source Selection in the Major Iranian Construction Companies. Buildings 2020, 10, 251. [CrossRef]

15. Faraji, A. Smart Contract Based Conceptual Model for Optimizing Risk Distribution in Construction Industry. In Proceedings of the 3rd International Conference on Applied Researches in Structual Engineering and Construction Management, Chicago, IL, USA, 20-25 May 2019.

16. Alsaedi, M.; Assaf, S.; Hassanain, M.A.; Abdallah, A. Factors affecting contractors' bidding decisions for construction projects in Saudi Arabia. Buildings 2019, 9, 33. [CrossRef]

17. Faraji, A.; Rashidi, M.; Khadir, P.; Perera, S. A Risk Analysis-Best Worst Method Based Model for Selection of the Most Appropriate Contract Strategy for Onshore Drilling Projects in the Iranian Petroleum Industry. Buildings 2021, 11, 97. [CrossRef]

18. Ravanshadnia, M.; Rajaie, H.; Abbasian, H.R. A comprehensive bid/no-bid decision making framework for construction companies. Iran. J. Sci. Technol. Trans. B Eng. 2011, 35, 95-103.

19. Chua, D.K.H.; Li, D.Z.; Chan, W.T. Case-based reasoning approach in bid decision making. J. Constr. Eng. Manag. 2001, 127, 35-45. [CrossRef]

20. Vale, J.; Barbosa, N.; Bertuzi, R.; Bandeira, A.M.; Vale, V.T. Intellectual Capital Change Management in the Construction Industry-The Case of an Inter-Organisational Collaboration. J. Open Innov. Technol. Mark. Complex. 2021, 7, 199. [CrossRef]

21. Teodorescu, M.; Korchagina, E. Applying Blockchain in the Modern Supply Chain Management: Its Implication on Open Innovation. J. Open Innov. Technol. Mark. Complex. 2021, 7, 80. [CrossRef]

22. Fellows, R.F.; Langford, D.A. Decision theory and tendering. Build. Technol. Manag. 1980, 18, 36-39.

23. Faraji, A.; Rashidi, M.; Perera, S. Text Mining Risk Assessment-Based Model to Conduct Uncertainty Analysis of the General Conditions of Contract in Housing Construction Projects: Case Study of the NSW GC21. J. Archit. Eng. 2021, $27,4021025$. [CrossRef]

24. Fine, B. Tendering strategy. Building 1975, 115-121.

25. Lin, C.-T.; Chen, Y.-T. Bid/no-bid decision-making-A fuzzy linguistic approach. Int. J. Proj. Manag. 2004, 22, 585-593. [CrossRef]

26. Lee, S.; Chang, L.-M. Bid-markup determination for microtunneling projects. Tunn. Undergr. Sp. Technol. 2004, 19, 151-163. [CrossRef]

27. Drew, D.S.; Skitmore, R.M. Prequalification and C-competitiveness. Omega 1993, 21, 363-375. [CrossRef]

28. Flanagan, R.; Norman, G. Risk analysis-an extension of price prediction techniques for building Work. Constr. Pap. 1982, 1, 27-34.

29. Laryea, S.; Hughes, W. How contractors price risk in bids: Theory and practice. Constr. Manag. Econ. 2008, 26, 911-924. [CrossRef]

30. Cheaitou, A.; Larbi, R.; Al Housani, B. Decision making framework for tender evaluation and contractor selection in public organizations with risk considerations. Socioecon. Plann. Sci. 2019, 68, 100620. [CrossRef]

31. Fayek, A.; Young, D.M.; Duffield, C.F. A survey of tendering practices in the Australian construction industry. Eng. Manag. J. 1998, 10, 29-34. [CrossRef]

32. Cagno, E.; Caron, F.; Mancini, M. A Bayesian Approach for the Bidding Phase to Estimate the Cause Probability of an Uncertain Event. Proj. Manag. 2002, 8, 83.

33. Dikmen, I.; Birgonul, M.T.; Gur, A.K. A case-based decision support tool for bid mark-up estimation of international construction projects. Autom. Constr. 2007, 17, 30-44. [CrossRef]

34. Bageis, A.S.; Fortune, C. Factors affecting the bid/no bid decision in the Saudi Arabian construction contractors. Constr. Manag. Econ. 2009, 27, 53-71. [CrossRef]

35. Marzouk, M.; Mohamed, E. Modeling bid/no bid decisions using fuzzy fault tree. Constr. Innov. 2017, 18, 90-108. [CrossRef]

36. Perera, B.; Wijewickrama, M.; Ranaweera, W.; Gamage, I.S.W. Significant factors influencing the bid mark-up decision of infrastructure projects in Sri Lanka. Int. J. Constr. Manag. 2019, 21, 1-15. [CrossRef]

37. Oyeyipo, O.; Odusami, K.T.; Ojelabi, R.A.; Afolabi, A.O. Factors affecting contractors' bidding decisions for construction projects in Nigeria. J. Constr. Dev. Ctries. 2016, 21, 21-35. [CrossRef]

38. Kumar, J.K.; Raj, S.V. Bid decision model for construction projects-A review. Mater. Today Proc. 2020, 22, 688-690. [CrossRef]

39. Pereira, L.; Fernandes, A.; Sempiterno, M.; Dias, Á.; Lopes da Costa, R.; António, N. Knowledge Management Maturity Contributes to Project-Based Companies in an Open Innovation Era. J. Open Innov. Technol. Mark. Complex. 2021, 7, 126. [CrossRef]

40. Tereshko, E.; Romanovich, M.; Rudskaya, I. Readiness of Regions for Digitalization of the Construction Complex. J. Open Innov. Technol. Mark. Complex. 2021, 7, 2. [CrossRef]

41. Kleber, D.M.; Juusola, K. Open Innovation-An Explorative Study on Value Co-Creation Tools for Nation Branding and Building a Competitive Identity. J. Open Innov. Technol. Mark. Complex. 2021, 7, 206. [CrossRef]

42. Mills, A. A systematic approach to risk management for construction. Struct. Surv. 2001, 9, 245-252. [CrossRef]

43. Mulholland, B.; Christian, J. Risk assessment in construction schedules. J. Constr. Eng. Manag. 1999, 125, 8-15. [CrossRef]

44. Baccarini, D. The concept of project complexity-A review. Int. J. Proj. Manag. 1996, 14, 201-204. [CrossRef]

45. Romero, M.C.; Lara, P.; Villalobos, J. Evolution of the Business Model: Arriving at Open Business Model Dynamics. J. Open Innov. Technol. Mark. Complex. 2021, 7, 86. [CrossRef]

46. Hadi, N.; Udin, U. Testing the Effectiveness of CSR Dimensions for Small Business Entrepreneurs. J. Open Innov. Technol. Mark. Complex. 2021, 7, 6. [CrossRef]

47. Butt, A.S.; Arshi, T.A.; Rao, V.; Tewari, V. Implications of Belt and Road Initiative for Supply Chain Management: A Holistic View. J. Open Innov. Technol. Mark. Complex. 2020, 6, 136. [CrossRef] 
48. Santana, G. Classification of construction projects by scales of complexity. Int. J. Proj. Manag. 1990, 8, 102-104. [CrossRef]

49. Turner, J.R.; Cochrane, R.A. Goals-and-methods matrix: Coping with projects with ill defined goals and/or methods of achieving them. Int. J. Proj. Manag. 1993, 11, 93-102. [CrossRef]

50. Williams, T.M. The need for new paradigms for complex projects. Int. J. Proj. Manag. 1999, 17, 269-273. [CrossRef]

51. Girmscheid, G.; Brockmann, C. The inherent complexity of large scale engineering projects. Proj. Perspect. 2008, $29,22-26$.

52. Vidal, L.; Marle, F. Understanding project complexity: Implications on project management. Kybernetes 2008, 37, $1094-1110$. [CrossRef]

53. Geraldi, J.; Maylor, H.; Williams, T. Now, let's make it really complex (complicated). Int. J. Oper. Prod. Manag. 2011, 31, 966-990. [CrossRef]

54. Ramasesh, R.V.; Browning, T.R. A conceptual framework for tackling knowable unknown unknowns in project management. J. Oper. Manag. 2014, 32, 190-204. [CrossRef]

55. He, Q.; Luo, L.; Hu, Y.; Chan, A.P.C. Measuring the complexity of mega construction projects in China-A fuzzy analytic network process analysis. Int. J. Proj. Manag. 2015, 33, 549-563. [CrossRef]

56. Carral, L.; Tarrío-Saavedra, J.; Iglesias, G.; San-Cristobal, J.R. Evaluation of the structural complexity of organisations and products in naval-shipbuilding projects. Ships Offshore Struct. 2020, 16, 670-685. [CrossRef]

57. GAPPS. Crawford-Ishikura Factor Table for Evaluating Roles. 2007. Available online: https://www.projectmanagement.com/ content/attachments/Primus1_201011023434.pdf (accessed on 1 October 2007).

58. IPMA \& AIPM. Complexity Matrix, 2015.

59. Poveda-Bautista, R.; Diego-Mas, J.-A.; Leon-Medina, D. Measuring the project management complexity: The case of information technology projects. Complexity 2018, 2018, 6058480. [CrossRef]

60. Dao, B.; Kermanshachi, S.; Shane, J.; Anderson, S. Project complexity assessment and management tool. Procedia Eng. 2016, 145, 491-496. [CrossRef]

61. Luo, L.; He, Q.; Xie, J.; Yang, D.; Wu, G. Investigating the relationship between project complexity and success in complex construction projects. J. Manag. Eng. 2017, 33, 4016036. [CrossRef]

62. Bakhshi, J. Exploring Project Complexities and Their Problems: A Critical Review of the Literature. Doctoral Dissertation, University of Adelaide, Adelaide, Australia, 2016.

63. Kermanshachi, S.; Dao, B.; Shane, J.; Anderson, S. Project complexity indicators and management strategies-A Delphi study. Procedia Eng. 2016, 145, 587-594. [CrossRef]

64. Abdou, S.M.; Yong, K.; Othman, M. Categorization of project complexity factors in Malaysian construction industry. Int. J. Prop. Sci. (E-ISSN 2229-8568) 2017, 7, 1-15. [CrossRef]

65. Cooke-Davies, T. Navigating Complexity. Proj. Manag. Institute, PMI. org/Pulse. 2013. Available online: https//www.pmi.org/ learning/thought-leadership/pulse/navigating-complexity (accessed on 1 December 2021).

66. Gidado, K.I. Project complexity: The focal point of construction production planning. Constr. Manag. Econ. 1996, 14, 213-225. [CrossRef]

67. Zolin, R.; Turner, R.; Remington, K. A model of project complexity: Distinguishing dimensions of complexity from severity. In Proceedings of the International Research Network of Project Management Conference (IRNOP), Berlin, Germany, 11-13 October 2009; pp. 1-30.

68. Maylor, H.; Vidgen, R.; Carver, S. Managerial complexity in project-based operations: A grounded model and its implications for practice. Proj. Manag. J. 2008, 39, S15-S26. [CrossRef]

69. Gransberg, D.D.; Shane, J.S.; Strong, K.; del Puerto, C.L. Project complexity mapping in five dimensions for complex transportation projects. J. Manag. Eng. 2013, 29, 316-326. [CrossRef]

70. Qureshi, S.M.; Kang, C. Analysing the organizational factors of project complexity using structural equation modelling. Int. J. Proj. Manag. 2015, 33, 165-176. [CrossRef]

71. Xia, B.; Chan, A.P.C. Measuring complexity for building projects: A Delphi study. Eng. Constr. Archit. Manag. 2012, 19, 7-24. [CrossRef]

72. He, Q.; Luo, L.; Wang, J.; Li, Y.; Zhao, L. Using analytic network process to analyze influencing factors of project complexity. In Proceedings of the 2012 International Conference on Management Science \& Engineering 19th Annual Conference Proceedings, Dallas, TX, USA, 20-22 September 2012; pp. 1781-1786.

73. Azim, S.W. Understanding and Managing Project Complexity; University of Manchester: Manchester, UK, 2010.

74. Bosch-Rekveldt, M.; Jongkind, Y.; Mooi, H.; Bakker, H.; Verbraeck, A. Grasping project complexity in large engineering projects: The TOE (Technical, Organizational and Environmental) framework. Int. J. Proj. Manag. 2011, 29, 728-739. [CrossRef]

75. Lee, G.; Xia, W. An Empirical Study on the Relationships between the Flexibility, Complexity and Performance of Information Systems Development Projects; University of Minnesota: Minneapolis, MN, USA, 2003.

76. Müller, R.; Turner, R. The influence of project managers on project success criteria and project success by type of project. Eur. Manag. J. 2007, 25, 298-309. [CrossRef]

77. Vidal, L.-A.; Marle, F.; Bocquet, J.-C. Measuring project complexity using the Analytic Hierarchy Process. Int. J. Proj. Manag. 2011, 29, 718-727. [CrossRef]

78. Davis, K. Different stakeholder groups and their perceptions of project success. Int. J. Proj. Manag. 2014, 32, 189-201. [CrossRef] 
79. Gardoni, P.; Reinschmidt, K.F.; Kumar, R. A probabilistic framework for Bayesian adaptive forecasting of project progress. Comput. Civ. Infrastruct. Eng. 2007, 22, 182-196. [CrossRef]

80. Geraldi, J.G. What complexity assessments can tell us about projects: Dialogue between conception and perception. Technol. Anal. Strateg. Manag. 2009, 21, 665-678. [CrossRef]

81. Lu, Y.; Luo, L.; Wang, H.; Le, Y.; Shi, Q. Measurement model of project complexity for large-scale projects from task and organization perspective. Int. J. Proj. Manag. 2015, 33, 610-622. [CrossRef]

82. Maylor, H.; Turner, N. Understand, reduce, respond: Project complexity management theory and practice. Int. J. Oper. Prod. Manag. 2017, 37, 1076-1093. [CrossRef]

83. Mikkelsen, M.F. Perceived project complexity: A survey among practitioners of project management. Int. J. Manag. Proj. Bus. 2020, 14, 680-698. [CrossRef]

84. Kermanshachi, S.; Dao, B.; Rouhanizadeh, B.; Shane, J.; Anderson, S. Development of the project complexity assessment and management framework for heavy industrial projects. Int. J. Constr. Educ. Res. 2020, 16, 24-42. [CrossRef]

85. Aznar, B.; Pellicer, E.; Davis, S.; Ballesteros-Perez, P. Factors affecting contractor's bidding success for international infrastructure projects in Australia. J. Civ. Eng. Manag. 2017, 23, 880-889. [CrossRef]

86. Leśniak, A. Statistical Methods in Bidding Decision Support for Construction Companies. Appl. Sci. 2021, 11, 5973. [CrossRef]

87. Sonmez, R.; Sözgen, B. A support vector machine method for bid/no bid decision making. J. Civ. Eng. Manag. 2017, 23, 641-649. [CrossRef]

88. Dello, A.; Yoshida, C. Online tendering and evaluation for public procurement in Tanzania. In Proceedings of the 2017 18th IEEE/ACIS International Conference on Software Engineering, Artificial Intelligence, Networking and Parallel/Distributed Computing (SNPD), Kanazawa, Japan, 26-28 June 2017; pp. 137-141.

89. Arkes, J. Regression Analysis: A Practical Introduction; Routledge: London, UK, 2019; ISBN 135101109X.

90. Westfall, P.H.; Arias, A.L. Understanding Regression Analysis: A Conditional Distribution Approach; CRC Press: Boca Raton, FL, USA, 2020; ISBN 1000069419.

91. Frost, J. Regression Analysis: An Intuitive Guide for Using and Interpreting Linear Models; Jim Publishing: Costa Mesa, CA, USA, 2019; ISBN 1735431184.

92. Ko, S.; Kim, W.; Lee, K. Exploring the Factors Affecting Technology Transfer in Government-Funded Research Institutes: The Korean Case. J. Open Innov. Technol. Mark. Complex. 2021, 7, 228. [CrossRef]

93. Argumedo-García, M.; Salas-Navarro, K.; Acevedo-Chedid, J.; Ospina-Mateus, H. Bibliometric Analysis of the Potential of Technologies in the Humanitarian Supply Chain. J. Open Innov. Technol. Mark. Complex. 2021, 7, 232. [CrossRef]

94. Tripathi, V.; Chattopadhyaya, S.; Mukhopadhyay, A.K.; Sharma, S.; Singh, J.; Pimenov, D.Y.; Giasin, K. An Innovative Agile Model of Smart Lean-Green Approach for Sustainability Enhancement in Industry 4.0. J. Open Innov. Technol. Mark. Complex. 2021, 7, 215. [CrossRef]

95. Kamp, L.M.; Meslin, T.A.J.; Khodaei, H.; Ortt, J.R. The Dynamic Business Model Framework—Illustrated with Renewable Energy Company Cases from Indonesia. J. Open Innov. Technol. Mark. Complex. 2021, 7, 231. [CrossRef]

96. Ali, M.A.; Hussin, N.; Haddad, H.; Al-Araj, R.; Abed, I.A. A Multidimensional View of Intellectual Capital: The Impact on Innovation Performance. J. Open Innov. Technol. Mark. Complex. 2021, 7, 216. [CrossRef]

97. Matisone, A.; Lace, N. Effective Venture Capital Market Development Concept. J. Open Innov. Technol. Mark. Complex. 2021, 7, 218. [CrossRef]

98. Drozd, R.; Wolniak, R. Systematic Assessment of Product Quality. J. Open Innov. Technol. Mark. Complex. 2021, 7, 235. [CrossRef]

99. Lim, C.S.; Mohamed, M.Z. Criteria of project success: An exploratory re-examination. Int. J. Proj. Manag. 1999, 17, $243-248$. [CrossRef]

100. Abdissa, G.; Ayalew, A.; Illés, C.B.; Dunay, A. Effects of Corporate Entrepreneurship Dimensions on Organizational Performance: Case of Small and Medium Enterprises in Holeta Town, Ethiopia. J. Open Innov. Technol. Mark. Complex. 2021, 7, 234. [CrossRef]

101. Millers, M.; Gaile-Sarkane, E. Management Practice in Small and Medium-Sized Enterprises: Problems and Solutions from the Perspective of Open Innovation. J. Open Innov. Technol. Mark. Complex. 2021, 7, 214. [CrossRef]

102. Marchena Sekli, G.F.; De La Vega, I. Adoption of Big Data Analytics and Its Impact on Organizational Performance in Higher Education Mediated by Knowledge Management. J. Open Innov. Technol. Mark. Complex. 2021, 7, 221. [CrossRef]

103. Sanchez, R.; Shibata, T. Modularity Design Rules for Architecture Development: Theory, Implementation, and Evidence from the Development of the Renault-Nissan Alliance "Common Module Family" Architecture. J. Open Innov. Technol. Mark. Complex. 2021, 7, 242. [CrossRef]

104. Kitsios, F.; Giatsidis, I.; Kamariotou, M. Digital Transformation and Strategy in the Banking Sector: Evaluating the Acceptance Rate of E-Services. J. Open Innov. Technol. Mark. Complex. 2021, 7, 204. [CrossRef]

105. Jin, S.; Kim, D. The Effects of Patents on the Relationship between R\&D Activities and Business Management Performance: Focus on South Korean Venture Companies. J. Open Innov. Technol. Mark. Complex. 2021, 7, 210. [CrossRef]

106. Yuana, R.; Prasetio, E.A.; Syarief, R.; Arkeman, Y.; Suroso, A.I. System Dynamic and Simulation of Business Model Innovation in Digital Companies: An Open Innovation Approach. J. Open Innov. Technol. Mark. Complex. 2021, 7, 219. [CrossRef] 